Article

\title{
Correlations between GIS-Based Urban Building Densification Analysis and Climate Guidelines for Mediterranean Courtyards
}

\author{
Juan Rojas-Fernández, Carmen Galán-Marín * (D), Jorge Roa-Fernández (i) and \\ Carlos Rivera-Gómez \\ Departamento de Construcciones Arquitectónicas 1, Escuela Técnica Superior de Arquitectura, \\ Universidad de Sevilla, Avda. Reina Mercedes, 2, 41012 Seville, Spain; jmrojas@us.es (Ju.R.-F.); \\ jroa@us.es (Jo.R.-F.); crivera@us.es (C.R.-G.) \\ * Correspondence: cgalan@us.es; Tel.: +34-954-556591
}

Received: 1 November 2017; Accepted: 28 November 2017; Published: 6 December 2017

\begin{abstract}
This study identifies and proposes A GIS-based exploration of the relationships between aspect ratio of inner courtyards, porosity of the urban fabric and the climatic factors where it is located. To perform that comparison, morphological and measurement methods have been used to delineate spatial boundaries of urban densification. This methodology has been applied to a case study in Spain, where regulation establishes several climatic zones. Examples of cities in these zones have been examined to establish possible correlations. This paper analyses the particularities of these different urban scenarios, considering the effects of climate on the real urban densification. The purpose of this study is to find a relationship between the historical inner courtyards dimensions and the climate of the zone where they are located. In order to frame the real thermal behaviour of the inner courtyard in the context of the vernacular typologies studied, a representative sample of inner courtyards has been selected. The monitoring data presented allow quantifying the courtyard's ability to temper the maximum temperature values.
\end{abstract}

Keywords: urban densification; GIS; inner courtyards; urban microclimate; courtyard design

\section{Introduction}

Among all the passive-cooling systems, the inner courtyard is one of the most effective and is used, primarily in warm climates. This effect is favourable during both winter and summer [1], and is more significant in the latter. In fact, there is a relationship between urban geometry, specifically in the layout and proportion of full and empty volumes and the distribution of urban heat islands in cities [2].

The most significant thermal phenomenon of a city in relation to the climate is the so-called urban heat island (UHI). The UHI intensity is the temperature difference between an urban and a rural site under the same climate conditions. Cities and towns are warmer at night than rural areas due to the absorption of solar radiation by the urban pavements and buildings. Urban morphology parameters, such as urban plan area density, geometry of the buildings and topographical features influence airflows in and around buildings and energy consumption on a regional scale [2,3]. In the same line, Jurelionis and Bouris [4] applied computational fluid dynamics methods in order to calculate surface pressure distributions on building surfaces for three city models and two wind directions. From another perspective, Garcia-Nevado et al. analysed the solar performance at the urban canyon intersections [5].

The UHI effect in our cities will be especially important in the future scenario of climate change. Recent measurements in Manchester show a summer maximum UHI intensity of $8^{\circ} \mathrm{C}$ [6]. In view of 
the negative UHI effects, many researchers have analysed mitigation strategies by simulating single blocks or neighbourhoods $[7,8]$. Some results have shown the importance of urban design on the microclimate of outdoor spaces [9-11]. Urban density plays an important role in the UHI effect, since a denser urban form results in multiple reflections of solar energy, and influences air convection [12,13].

In this research we focused on "patios", i.e., open inner courtyards or open-air atriums, which are very common in Spanish or Spanish-American houses among other warm regions. Previous researchers have proven that courtyards show thermal mitigation properties in warm climates such as Mediterranean ones, with a range of temperatures up to $8^{\circ} \mathrm{C}$ lower inside the courtyard than the outer space during the warmest hours of the day [14,15]. Al-Hemiddi et al. concluded that the use of courtyards is an applicable strategy during the warmest periods in desert regions [16]. Cantón et al. found that the performance of inner courtyards at night is useful due to the higher convective and radiative cooling capacity of open spaces [17]. Kubota et al. identified the thermal functions of internal traditional Chinese courtyards [18] and Taleghani et al. also considered the most severe climate scenario for the Netherlands for the year 2050. Urban heat mitigation strategies that moderate the microclimate of courtyards were investigated [19]. In this sense, due to their thermal heat mitigation up to $8{ }^{\circ} \mathrm{C}$, the presence of courtyards in cities, their size and geometric characteristics, would imply a possible way to mitigate the UHI effects.

The interactions between urban geometry and surface properties under a specific climate generate microclimates. These interactions were first discussed by Olgyay [20], Oke [21] and Givoni [22]. They analysed the thermal impact of urban typologies in different climates and concluded general design guidelines. They stated that architectural forms, surface materials and urban morphology can affect the microclimate environment. On this topic, courtyard blocks were studied in several climates implying different benefits. A comprehensive study on urban courtyards was done by Yezioro et al. [23] using the SHADING program. Steemers et al. [24] proposed six archetypical generic urban forms for London. They concluded that large courtyards are environmentally adequate in cold climates, where they can act as sun concentrators and retain their sheltering effect against cold winds under certain geometrical conditions. This is to say, urban geometry shaped by the building typology, has opposite effects for different seasons, satisfying a demand for compactness in summer, to ensure protection from the sunlight, and openness in winter, to provide solar access.

At this point it seems to be interesting for the development of these studies to be able to compare different urban fabrics. Considering the amount of data required for the analysis, Geographic Information System (GIS) tools are most adequate to do this. GIS is a system of hardware, software, data, people, organisations and institutional arrangements for the collection, storage, analysis and dissemination of information about areas of the Earth [24,25]. In general, GIS measures aspects of geographic phenomena as processes; they display these measurements, usually in the form of a computer database, so as to emphasise spatial themes, entities and relationships.

Assuming the current scenario regarding the risk of climate change, the relationship between urban geometry and microclimate is a relevant topic for both urban planning and urban climatology, as it significantly influences the thermal comfort of individuals and new energy efficiency requirements.

This research is supported on the existence of previous empirical results of courtyard microclimates due to its dimensional characteristics [14-18]. The aim of the present paper is to contrast if these courtyard microclimates have a consequence and a correlation with vernacular typologies of courtyards in the different Spanish climatic zones. Previous research [26-31] was usually based on specific case studies but this paper presents several urban scale studies considering the geometry of thousands of courtyards. GIS allows us to identify a statistical relationship between the proportion and geometric characteristics of the courtyards and the climate where they are located.

\section{Methodology}

The tool used was QGIS [32] release 2.18, the leading Open Source GIS. QGIS supports numerous vector, raster, and database formats and functionalities. 
In general, there are two basic methods in GIS to do overlay analysis: Entities overlay (in our case field polygons) and overlay on raster data models. The entities overlay was used in this research to identify the polygons that fulfil certain criteria. Data collection was done by means of Shapefile vector files, generated by the Dirección General del Catastro [33], which belongs to the Spanish Ministry. These files follow the INSPIRE [34] (Infrastructure for spatial information in Europe European) Directive. The INSPIRE Directive aims to create a European Union spatial data infrastructure for the purposes of EU environmental policies and regulations which may have an impact on the environment. This European Spatial Data Infrastructure enables the sharing of environmental spatial information among public sector organizations, facilitating public access to spatial information across Europe and assisting in policy-making across boundaries.

A preliminary GIS analysis led us to focus on the data contained in the constructed space and parcels layers of these files that contain the information about the constructed areas of the city and empty spaces (inner courtyards) including also number and distribution of levels inside every building plot. The area considered corresponds to the historic centre of each city according to local urban regulations. The limits between the streets and the built elements were defined and the heights of the different constructions were related to each of them. Figure 1 shows an example (Córdoba) where every building plot that contains an inner courtyard has been marked (different colours are used depending on the courtyard size). Courtyards or inner courtyards are considered, on the condition that they are not in the facades or limited by the streets.
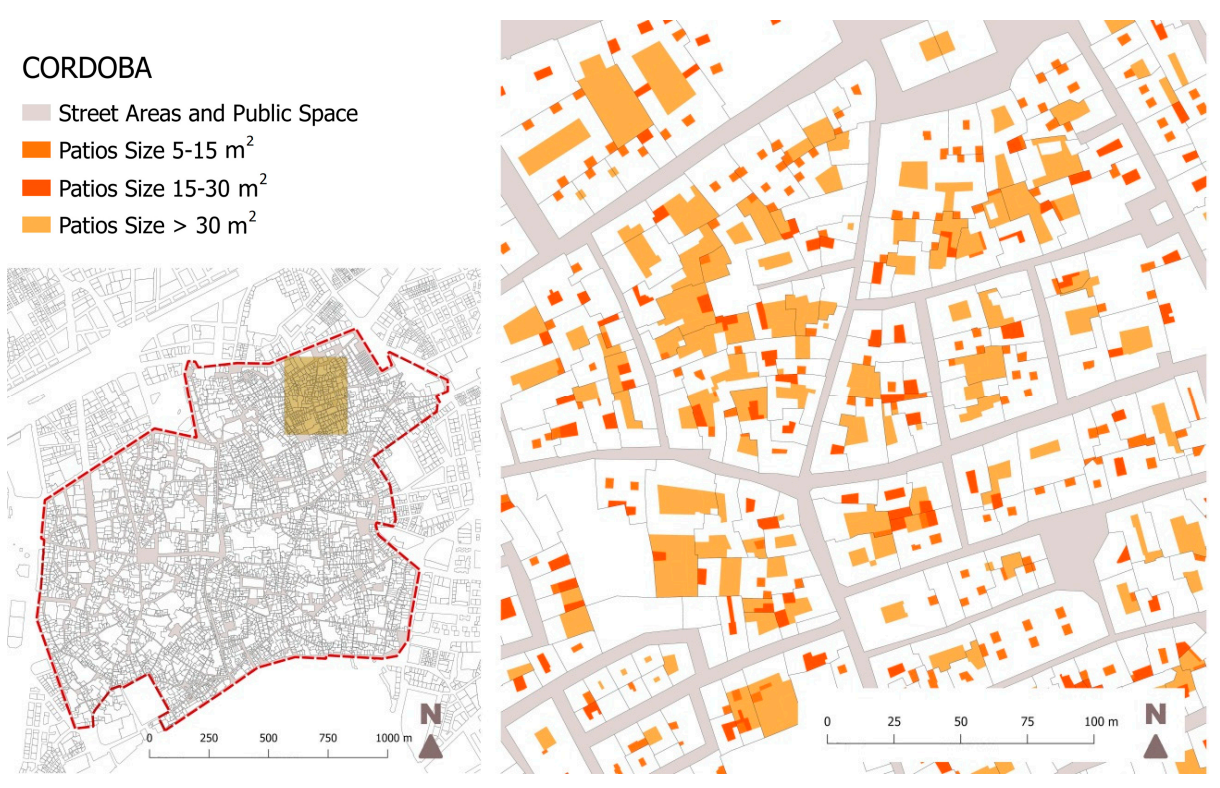

Figure 1. Córdoba city centre, every construction that contains an inner courtyard was marked.

Data processing allowed us to calculate the Porosity Index (PI) of every block and the percentage of plots with inner courtyards. PI is a parameter that provides an overview of the historical centre, how perforated it is, as a general ratio between solid and void in the studied area. A higher PI means more voids. This is to say, an empty plot has a porosity value of 100 , while a 0 value means a fully dense plot without courtyards. Neat Porosity Index (NPI) was calculated considering only the urban plots that contain a courtyard. All public spaces such as street areas, squares, etc. have not been considered in the calculations affecting only the insight of the built plot both for PI and NPI.

In the final Appendix A detail, data and plans that reflect the specific situation of each of the cities analysed are showed. Figures A1-A6 in the Appendix A represent in a bar chart, the most typical inner courtyards area for every city, and so the most representative inner courtyards were chosen (those whose area is between $5-15 \mathrm{~m}^{2}$ and $15-30 \mathrm{~m}^{2}$ ). Also, the average height of the construction around the 
courtyard was determined. The tendency of historical courtyards to possess square dimensions allows us to easily determine the width. This simplification is used to calculate the Aspect Ratio (AR) of the courtyard (Figure 2). AR, is the correlation between the height and width of the inner courtyards as described by Hall [35]:

$$
\mathrm{AR}=\mathrm{hmax} / \mathrm{W} \text {. }
$$

where hmax = maximum height of inner courtyards and $\mathrm{W}=$ width of inner courtyard (inner courtyards were considered square in the present study).
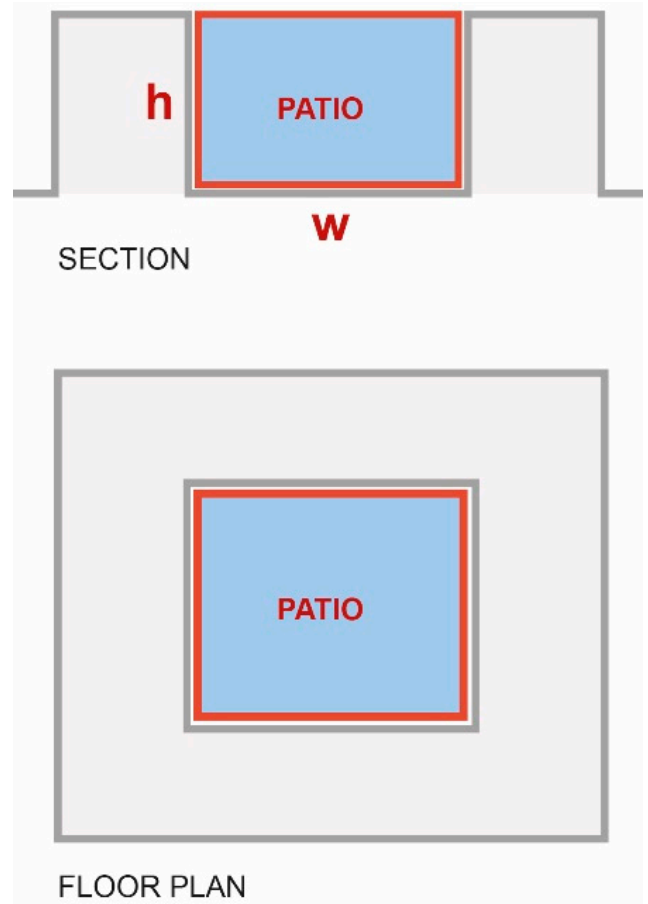

Figure 2. Aspect Ratio ( $A R=h / W)$ of an inner courtyards.

In the specific literature, there are several studies that relate AR to heat flows in urban settings [36] and with the albedo heterogeneity in cities [37].

\section{Case Study}

Meteorological and climatic conditions of cities constitute a relevant issue for urban design and urban studies, as they affect human thermal comfort both outdoors and indoors, influencing the appreciation and use of open spaces and, indirectly, the energy consumption of buildings for heating, cooling and ventilation. These issues have been reflected in the urban and constructive regulations of the different countries.

\subsection{Spanish Regulations}

In the present study, the distribution and size of the courtyards in different cities of the Spanish geography are analysed. The research tries to establish a relation between the geometric characteristics of the courtyards and the different climatic zones. In order to calculate the different climatic zones, it is necessary to obtain the parameters of Winter Severity Index (WSI) and Summer Severity Index (SSI). These values, for each location, are calculated with the statistical average temperature during the months of winter and summer respectively. If it is considered an excessively low or excessively high temperature, energy demands for heating or cooling are involved. The WSI is given in the Spanish regulations [38], from lowest to highest, by the letters A-E (Figure 3a). In addition, the SSI, by numbers $1-4$, where 1 refers to the smallest and 4 the highest. There is no specific map published 
in [38] for SSI index. According to these standards, Table 1 displays columns corresponding to all winter classifications, being different summer severity ranks grouped in several cases.

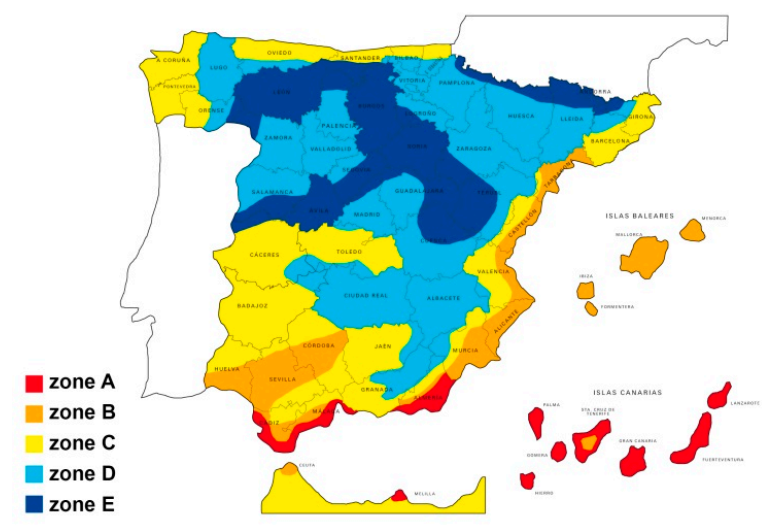

(a)

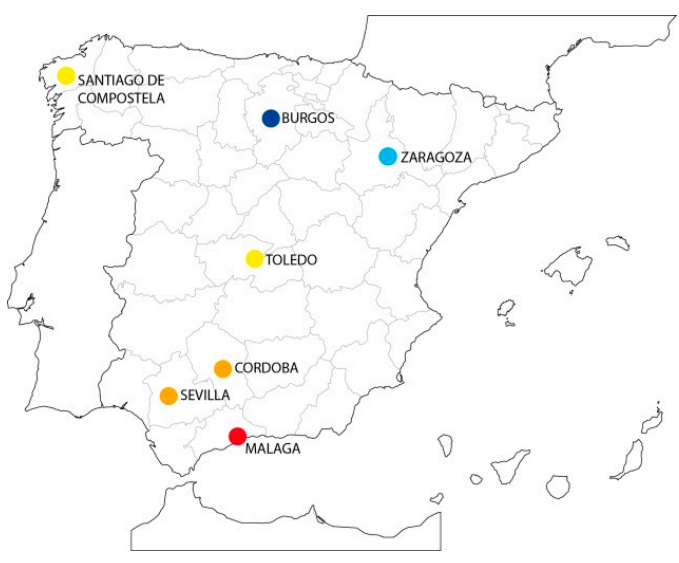

(b)

Figure 3. (a) Geographic distribution of Spanish climatic zones per CTE [38]; (b) Location of the different cities considered in the study.

Table 1. Classification of Spanish climatic zones as per national regulations [38].

\begin{tabular}{lccccc}
\hline & A4 & B4 & C4 & \multirow{2}{*}{ E1 } \\
\cline { 2 - 5 } SSI (Summer) & \multirow{4}{*}{ B3 } & C3 & D3 \\
& A3 & B3 & D2 & \\
& \multicolumn{4}{c}{ C1 } & D1 \\
\hline \multicolumn{4}{c}{ WSI (Winter) }
\end{tabular}

For the limitation of energy demand, the Spanish regulations [38], establish different climatic zones, identified by a letter, corresponding to the winter division, and a number, corresponding to the summer division. In this way, twelve structured climatic zones are established according to the following table and map.

\subsection{Cities Studied}

To perform a study sufficiently representative of the typological variety of urban structures, seven cities were selected from the twelve above-mentioned climatic zones. The study focuses on the relation between urban courtyard typology and climate zones, starting from the hypothesis that there is an adaptation of the constructive solutions to the microclimatic possibilities of the courtyards in different locations.

The selected cities (Figure 3b) were: Malaga (A3), Seville (B4), Cordoba (B4), Toledo (C4), Santiago (C1), Zaragoza (D3) and Burgos (E1). These cities are listed by their WSI, being Malaga the one with the warmest temperatures and Burgos the lowest. However, looking at the SSI, we can notice that Seville, Cordoba and Toledo all have higher climatic severities in summer compared to Malaga and Zaragoza, while Santiago and Burgos are the coolest.

The selection included cities in the most extreme climatic zones (A3-E1) and the analysis was repeated in cities with different urban configurations but a similar climatic zone in order to corroborate the direct relationship between the geometry of the inner courtyards and the climate of the city, as in the case of Seville and Cordoba, both B4. From the cities selected, samples of the urban layout corresponding to the oldest part of the city or historic centre were taken. This was done to avoid the most recent areas where current urban regulations have determined standardised courtyard geometry. 


\subsection{Results}

All the seven Spanish cities mentioned have been analysed. City centres were delimited as representatives of the vernacular architecture. Table 2 shows the results of courtyard percentages in the seven different climatic zones analysed and the total number of courtyards for each of the cities in the city centre area. Note that the city maps are not represented on the same scale, but depending on the total size of the city.

These maps allow us to calculate the porosity index of every city and the percentage of plots with courtyards, as already summarized in Table 2. In spite of the fact that due to its size the cities differ from 919 urban plots in Burgos to 8139 urban plots in the case of Seville, these different sizes allow a more objective calculation of the neat porosity of the city.

Table 2. Porosity index and percentage of plots with courtyard of every city analysed.

\begin{tabular}{ccccccccc}
\hline & & BU & CO & MA & SE & SA & TO & ZA \\
\hline Units & Urban plots & 919 & 4625 & 2900 & 8139 & 1397 & 2542 & 2849 \\
Units & Plots with courtyard & 560 & 3790 & 1470 & 6263 & 575 & 1649 & 2164 \\
$\%$ & Percentage & 61 & 82 & 51 & 77 & 41 & 65 & 76 \\
$\mathbf{m}^{\mathbf{2}}$ & Total Courtyard Surface & 43,028 & 267,956 & 893,08 & 384,504 & 56,077 & 87,632 & 200,522 \\
$\mathbf{\%}$ & PI & 10 & 15 & 5 & 12 & 11 & 10 & 14 \\
$\%$ & NPI & 17 & 19 & 11 & 16 & 28 & 15 & 18 \\
\hline
\end{tabular}

$\mathrm{BU}=$ Burgos, $\mathrm{CO}=$ Cordoba, $\mathrm{MA}=$ Malaga, $\mathrm{SE}=$ Seville, $\mathrm{SA}=$ Santiago, $\mathrm{TO}$ = Toledo, $\mathrm{ZA}=$ Zaragoza.

NPI provides an orientation of the relation of the plots with courtyards. Santiago for example, has very few inner courtyards (only $41 \%$ of the plots). Nevertheless, their size is bigger (NPI $=28$ ). Besides, $82 \%$ of the plots in Cordoba include courtyards (the largest proportion), displaying however a porosity like Zaragoza's, i.e., in spite of the higher number of courtyards per plot, they present a smaller surface.

According to Table 2, the total number of plots with courtyards and the total percentage of them show how rooted the courtyard culture is in some cities, basically due to their Mediterranean tradition. Seville and Cordoba exceed 6000 and 3700 plots with courtyards, respectively.

Table 3. Number of inner courtyards between 5 and $15 \mathrm{~m}^{2}$ for every city the analysed.

\begin{tabular}{|c|c|c|c|c|c|c|c|c|c|c|c|c|c|}
\hline \multicolumn{2}{|c|}{$\begin{array}{l}\text { Height of the Building } \\
\text { (No. of Levels) }\end{array}$} & \multirow{2}{*}{$\begin{array}{l}\text { I } \\
8\end{array}$} & \multirow{2}{*}{$\begin{array}{l}\text { II } \\
97\end{array}$} & \multirow{2}{*}{$\begin{array}{c}\text { III } \\
199\end{array}$} & \multirow{2}{*}{$\begin{array}{c}\text { IV } \\
270\end{array}$} & \multirow{2}{*}{$\frac{\mathbf{V}}{174}$} & \multirow{2}{*}{$\begin{array}{l}\text { VI } \\
97\end{array}$} & \multirow{2}{*}{$\begin{array}{c}\text { VII } \\
40\end{array}$} & \multirow{2}{*}{$\begin{array}{l}\text { VIII } \\
28\end{array}$} & \multirow{2}{*}{$\begin{array}{l}\text { IX } \\
16\end{array}$} & \multirow{2}{*}{$\begin{array}{c}X \\
11\end{array}$} & \multirow{2}{*}{$\begin{array}{c}\mathbf{X I} \\
1\end{array}$} & \multirow{2}{*}{$\frac{\text { XII }}{1}$} \\
\hline $\begin{array}{l}\text { Malaga } \\
\text { MA-A3 }\end{array}$ & $\begin{array}{l}\text { Total no. of } \\
\text { courtyards }\end{array}$ & & & & & & & & & & & & \\
\hline & Total (\%) & 1 & 10 & 21 & 29 & 18 & 10 & 4 & 3 & 2 & 1 & 0 & 0 \\
\hline \multirow[t]{2}{*}{$\begin{array}{l}\text { Seville } \\
\text { SE-B4 }\end{array}$} & $\begin{array}{l}\text { Total no. of } \\
\text { courtyards }\end{array}$ & 59 & 532 & 2015 & 2278 & 971 & 186 & 32 & 20 & 13 & 2 & 0 & 0 \\
\hline & Total (\%) & 1 & 9 & 33 & 37 & 16 & 3 & 1 & 0 & 0 & 0 & 0 & 0 \\
\hline \multirow[t]{2}{*}{$\begin{array}{l}\text { Cordoba } \\
\text { CO-B4 }\end{array}$} & $\begin{array}{l}\text { Total no. of } \\
\text { courtyards }\end{array}$ & 115 & 1248 & 1124 & 609 & 353 & 114 & 43 & 6 & 6 & 3 & 0 & 0 \\
\hline & Total (\%) & 3 & 34 & 31 & 17 & 10 & 3 & 1 & 0 & 0 & 0 & 0 & 0 \\
\hline \multirow[t]{2}{*}{$\begin{array}{l}\text { Toledo } \\
\text { TO-C4 }\end{array}$} & $\begin{array}{l}\text { Total no. of } \\
\text { courtyards }\end{array}$ & 0 & 357 & 583 & 270 & 56 & 5 & 0 & 0 & 0 & 0 & 0 & 0 \\
\hline & Total (\%) & 0 & 28 & 46 & 21 & 4 & 0 & 0 & 0 & 0 & 0 & 0 & 0 \\
\hline \multirow[t]{2}{*}{$\begin{array}{l}\text { Santiago } \\
\text { SA-C1 }\end{array}$} & $\begin{array}{l}\text { Total no. of } \\
\text { courtyards }\end{array}$ & 20 & 42 & 111 & 88 & 25 & 9 & 7 & 8 & 0 & 2 & 0 & 0 \\
\hline & Total (\%) & 6 & 13 & 36 & 28 & 8 & 3 & 2 & 3 & 0 & 1 & 0 & 0 \\
\hline \multirow[t]{2}{*}{$\begin{array}{l}\text { Zaragoza } \\
\text { ZA-D3 }\end{array}$} & $\begin{array}{l}\text { Total no. of } \\
\text { courtyards }\end{array}$ & 30 & 24 & 109 & 332 & 509 & 337 & 164 & 58 & 30 & 17 & 8 & 1 \\
\hline & Total (\%) & 2 & 1 & 7 & 20 & 31 & 21 & 10 & 4 & 2 & 1 & 0 & 0 \\
\hline \multirow[t]{2}{*}{$\begin{array}{l}\text { Burgos } \\
\text { BU-E1 }\end{array}$} & $\begin{array}{l}\text { Total no. of } \\
\text { courtyards }\end{array}$ & 12 & 14 & 10 & 45 & 117 & 87 & 28 & 20 & 2 & 0 & 1 & 0 \\
\hline & Total (\%) & 4 & 4 & 3 & 13 & 35 & 26 & 8 & 6 & 1 & 0 & 0 & 0 \\
\hline
\end{tabular}


Conversely, the number of courtyards in Toledo, Zaragoza and Malaga is less between 1470 and 2164 and, lastly, about 500 in Burgos and Santiago. On the other hand, the porosity index remains between $10 \%$ and $15 \%$ for all cities except Malaga, indicating that despite having fewer plots with courtyards, the ratio between built and unbuilt spaces remains constant.

Comparing the results, the most typical sizes of courtyards at this domestic scale were $5-15 \mathrm{~m}^{2}$ and $15-30 \mathrm{~m}^{2}$. These two sizes have been studied in depth and results are shown in Table 3. Herein, the height of the building (in number of levels/floors) detected for these inner courtyards is presented.

In order to establish how, certain geometric characteristics of the inner courtyards in traditional buildings are related to the climate in which they are constructed, the influence of the AR is studied. In Tables 3 and 4 the first row refers to the height of the building (number of levels, in Roman numbers) while in Tables 5 and 6 the first row shows AR (Aspect Ratio, in Arabic numbers).

Table 4. Number of inner courtyards between 15 and $30 \mathrm{~m}^{2}$ for every city the analysed.

\begin{tabular}{|c|c|c|c|c|c|c|c|c|c|c|c|c|c|}
\hline \multicolumn{2}{|c|}{$\begin{array}{l}\text { Height of the Building } \\
\text { (No. of Levels) }\end{array}$} & \multirow{2}{*}{$\begin{array}{c}\mathbf{I} \\
5\end{array}$} & \multirow{2}{*}{$\begin{array}{c}\text { II } \\
64\end{array}$} & \multirow{2}{*}{$\begin{array}{c}\text { III } \\
118\end{array}$} & \multirow{2}{*}{$\begin{array}{c}\text { IV } \\
168\end{array}$} & \multirow{2}{*}{$\begin{array}{c}\text { V } \\
143\end{array}$} & \multirow{2}{*}{$\begin{array}{l}\text { VI } \\
46\end{array}$} & \multirow{2}{*}{$\begin{array}{c}\text { VII } \\
38\end{array}$} & \multirow{2}{*}{$\begin{array}{c}\text { VIII } \\
29\end{array}$} & \multirow{2}{*}{$\begin{array}{l}\text { IX } \\
25\end{array}$} & \multirow{2}{*}{$\begin{array}{c}\mathbf{X} \\
10\end{array}$} & \multirow{2}{*}{$\begin{array}{r}\mathbf{X I} \\
1\end{array}$} & \multirow{2}{*}{$\begin{array}{r}\text { XII } \\
5\end{array}$} \\
\hline $\begin{array}{l}\text { Malaga } \\
\text { MA-A3 }\end{array}$ & $\begin{array}{l}\text { Total no. of } \\
\text { courtyards }\end{array}$ & & & & & & & & & & & & \\
\hline & Total (\%) & 1 & 10 & 18 & 26 & 22 & 7 & 6 & 4 & 4 & 2 & 0 & 1 \\
\hline \multirow[t]{2}{*}{$\begin{array}{l}\text { Seville } \\
\text { SE-B4 }\end{array}$} & $\begin{array}{l}\text { Total no. of } \\
\text { courtyards }\end{array}$ & 53 & 353 & 913 & 625 & 199 & 32 & 24 & 31 & 5 & 0 & 0 & 0 \\
\hline & Total (\%) & 2 & 16 & 41 & 28 & 9 & 1 & 1 & 1 & 0 & 0 & 0 & 0 \\
\hline \multirow[t]{2}{*}{$\begin{array}{l}\text { Cordoba } \\
\text { CO-B4 }\end{array}$} & $\begin{array}{l}\text { Total no. of } \\
\text { courtyards }\end{array}$ & 96 & 882 & 476 & 146 & 97 & 35 & 45 & 15 & 19 & 6 & 0 & 0 \\
\hline & Total (\%) & 5 & 49 & 26 & 8 & 5 & 2 & 2 & 1 & 1 & 0 & 0 & 0 \\
\hline \multirow[t]{2}{*}{$\begin{array}{l}\text { Toledo } \\
\text { TO-C4 }\end{array}$} & $\begin{array}{l}\text { Total no. of } \\
\text { courtyards }\end{array}$ & 0 & 180 & 252 & 84 & 31 & 6 & 0 & 0 & 0 & 0 & 0 & 0 \\
\hline & Total (\%) & 0 & 33 & 46 & 15 & 6 & 1 & 0 & 0 & 0 & 0 & 0 & 0 \\
\hline \multirow[t]{2}{*}{$\begin{array}{l}\text { Santiago } \\
\text { SA-C1 }\end{array}$} & $\begin{array}{l}\text { Total no. of } \\
\text { courtyards }\end{array}$ & 10 & 51 & 75 & 41 & 10 & 4 & 0 & 2 & 0 & 0 & 0 & 0 \\
\hline & Total (\%) & 5 & 26 & 39 & 21 & 5 & 2 & 0 & 1 & 0 & 0 & 0 & 0 \\
\hline \multirow[t]{2}{*}{$\begin{array}{l}\text { Zaragoza } \\
\text { ZA-D3 }\end{array}$} & $\begin{array}{l}\text { Total no. of } \\
\text { courtyards }\end{array}$ & 27 & 108 & 280 & 259 & 201 & 98 & 25 & 11 & 0 & 0 & 0 & 0 \\
\hline & Total (\%) & 3 & 11 & 28 & 26 & 20 & 10 & 2 & 1 & 0 & 0 & 0 & 0 \\
\hline \multirow[t]{2}{*}{$\begin{array}{l}\text { Burgos } \\
\text { BU-E1 }\end{array}$} & $\begin{array}{l}\text { Total no. of } \\
\text { courtyards }\end{array}$ & 7 & 23 & 12 & 25 & 41 & 41 & 34 & 27 & 1 & 1 & 0 & 0 \\
\hline & Total (\%) & 3 & 11 & 6 & 12 & 19 & 19 & 16 & 13 & 0 & 0 & 0 & 0 \\
\hline
\end{tabular}

Tables 5 and 6 allow to classify the cities in two different groups: those cities with low heights and low AR, and those with high heights and high AR. Different heights obey to different urban conceptions: those cities with more Muslim-court culture, have maintained lower building heights balancing the small surface of the courtyards (more numerous and spread) in the search for an efficient Aspect Ratio (AR: 2.00-2.80-2.60). These are Seville, Toledo and Córdoba, with heights around 3 levels. Figures 4 and 5 allow to compare the results obtained.

Table 5. Numerical values for AR calculated for inner courtyards between 5 and $15 \mathrm{~m}^{2}$.

\begin{tabular}{|c|c|c|c|c|c|c|c|c|c|c|c|c|c|}
\hline & AR & 1 & 2 & 3 & 4 & 5 & 6 & 7 & 8 & 9 & 10 & 11 & 12 \\
\hline \multirow[t]{2}{*}{$\begin{array}{l}\text { Malaga } \\
\text { MA-A3 }\end{array}$} & $\begin{array}{l}\text { Total no. of } \\
\text { courtyards }\end{array}$ & 4 & 89 & 213 & 299 & 169 & 77 & 47 & 25 & 15 & 4 & 0 & 0 \\
\hline & Total (\%) & 0 & 9 & 23 & 32 & 18 & 8 & 5 & 3 & 2 & 0 & 0 & 0 \\
\hline \multirow[t]{2}{*}{$\begin{array}{l}\text { Seville } \\
\text { SE-B4 }\end{array}$} & $\begin{array}{l}\text { Total no. of } \\
\text { courtyards }\end{array}$ & 52 & 557 & 2178 & 2167 & 883 & 188 & 58 & 16 & 2 & 7 & 0 & 0 \\
\hline & Total (\%) & 1 & 9 & 36 & 35 & 14 & 3 & 1 & 0 & 0 & 0 & 0 & 0 \\
\hline
\end{tabular}


Table 5. Cont.

\begin{tabular}{|c|c|c|c|c|c|c|c|c|c|c|c|c|c|}
\hline & AR & 1 & 2 & 3 & 4 & 5 & 6 & 7 & 8 & 9 & 10 & 11 & 12 \\
\hline \multirow[t]{2}{*}{$\begin{array}{l}\text { Cordoba } \\
\text { CO-B4 }\end{array}$} & $\begin{array}{l}\text { Total no. of } \\
\text { courtyards }\end{array}$ & 94 & 1271 & 1227 & 594 & 275 & 104 & 40 & 10 & 6 & 0 & 0 & 0 \\
\hline & Total (\%) & 3 & 35 & 34 & 16 & 8 & 3 & 1 & 0 & 0 & 0 & 0 & 0 \\
\hline \multirow[t]{2}{*}{$\begin{array}{l}\text { Toledo } \\
\text { TO-C4 }\end{array}$} & $\begin{array}{l}\text { Total no. of } \\
\text { courtyards }\end{array}$ & 0 & 253 & 542 & 343 & 104 & 24 & 4 & 1 & 0 & 0 & 0 & 0 \\
\hline & Total (\%) & 0 & 20 & 43 & 27 & 8 & 2 & 0 & 0 & 0 & 0 & 0 & 0 \\
\hline \multirow[t]{2}{*}{$\begin{array}{l}\text { Santiago } \\
\text { SA-C1 }\end{array}$} & $\begin{array}{l}\text { Total no. of } \\
\text { courtyards }\end{array}$ & 10 & 35 & 89 & 96 & 42 & 19 & 12 & 5 & 1 & 3 & 0 & 0 \\
\hline & Total (\%) & 3 & 11 & 29 & 31 & 13 & 6 & 4 & 2 & 0 & 1 & 0 & 0 \\
\hline \multirow[t]{2}{*}{$\begin{array}{l}\text { Zaragoza } \\
\text { ZA-D3 }\end{array}$} & $\begin{array}{l}\text { Total no. of } \\
\text { courtyards }\end{array}$ & 19 & 38 & 120 & 298 & 430 & 343 & 189 & 106 & 34 & 20 & 14 & 7 \\
\hline & Total (\%) & 1 & 2 & 7 & 18 & 27 & 21 & 12 & 7 & 2 & 1 & 1 & 0 \\
\hline \multirow[t]{2}{*}{$\begin{array}{l}\text { Burgos } \\
\text { BU-E1 }\end{array}$} & $\begin{array}{l}\text { Total no. of } \\
\text { courtyards }\end{array}$ & 6 & 14 & 14 & 45 & 85 & 78 & 58 & 27 & 7 & 1 & 0 & 1 \\
\hline & Total (\%) & 2 & 4 & 4 & 13 & 25 & 23 & 17 & 8 & 2 & 0 & 0 & 0 \\
\hline
\end{tabular}

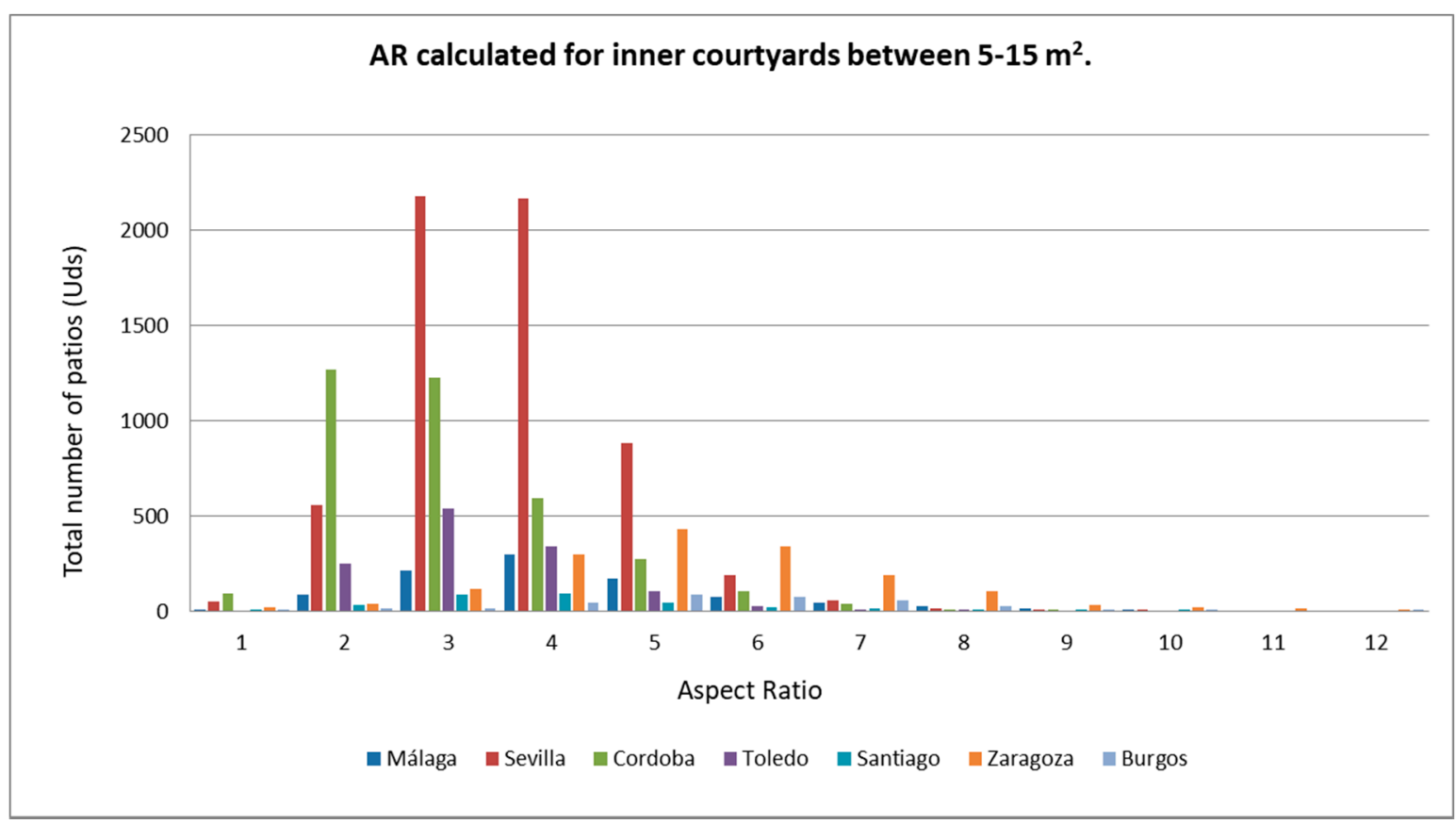

Figure 4. AR calculated for inner courtyards between 5 and $15 \mathrm{~m}^{2}$ for every city the analysed.

Table 6. Numerical values for AR calculated for inner courtyards between 15 and $30 \mathrm{~m}^{2}$.

\begin{tabular}{|c|c|c|c|c|c|c|c|c|c|c|c|c|c|}
\hline & AR & 1 & 2 & 3 & 4 & 5 & 6 & 7 & 8 & 9 & 10 & 11 & 12 \\
\hline \multirow[t]{2}{*}{$\begin{array}{l}\text { Malaga } \\
\text { MA-A3 }\end{array}$} & $\begin{array}{l}\text { Total no. of } \\
\text { courtyards }\end{array}$ & 9 & 140 & 248 & 145 & 46 & 39 & 22 & 2 & 1 & 1 & 1 & 0 \\
\hline & Total (\%) & 1 & 21 & 38 & 22 & 7 & 6 & 3 & 0 & 0 & 0 & 0 & 0 \\
\hline \multirow[t]{2}{*}{$\begin{array}{l}\text { Seville } \\
\text { SE-B4 }\end{array}$} & $\begin{array}{l}\text { Total no. of } \\
\text { courtyards }\end{array}$ & 124 & 1062 & 862 & 131 & 36 & 18 & 2 & 0 & 0 & 0 & 0 & 0 \\
\hline & Total (\%) & 6 & 48 & 39 & 6 & 2 & 1 & 0 & 0 & 0 & 0 & 0 & 0 \\
\hline \multirow[t]{2}{*}{$\begin{array}{l}\text { Cordoba } \\
\text { CO-B4 }\end{array}$} & $\begin{array}{l}\text { Total no. of } \\
\text { courtyards }\end{array}$ & 294 & 1104 & 247 & 86 & 51 & 31 & 3 & 1 & 0 & 0 & 0 & 0 \\
\hline & Total (\%) & 16 & 61 & 14 & 5 & 3 & 2 & 0 & 0 & 0 & 0 & 0 & 0 \\
\hline
\end{tabular}


Table 6. Cont.

\begin{tabular}{|c|c|c|c|c|c|c|c|c|c|c|c|c|c|}
\hline & AR & 1 & 2 & 3 & 4 & 5 & 6 & 7 & 8 & 9 & 10 & 11 & 12 \\
\hline \multirow[t]{2}{*}{$\begin{array}{l}\text { Toledo } \\
\text { TO-C4 }\end{array}$} & $\begin{array}{l}\text { Total no. of } \\
\text { courtyards }\end{array}$ & 0 & 390 & 146 & 17 & 0 & 0 & 0 & 0 & 0 & 0 & 0 & 0 \\
\hline & Total (\%) & 0 & 71 & 26 & 3 & 0 & 0 & 0 & 0 & 0 & 0 & 0 & 0 \\
\hline \multirow[t]{2}{*}{$\begin{array}{l}\text { Santiago } \\
\text { SA-C1 }\end{array}$} & $\begin{array}{l}\text { Total no. of } \\
\text { courtyards }\end{array}$ & 19 & 97 & 61 & 13 & 2 & 1 & 0 & 0 & 0 & 0 & 0 & 0 \\
\hline & Total (\%) & 10 & 50 & 32 & 7 & 1 & 1 & 0 & 0 & 0 & 0 & 0 & 0 \\
\hline \multirow[t]{2}{*}{$\begin{array}{l}\text { Zaragoza } \\
\text { ZA-D3 }\end{array}$} & $\begin{array}{l}\text { Total no. of } \\
\text { courtyards }\end{array}$ & 27 & 108 & 280 & 259 & 201 & 98 & 25 & 11 & 0 & 0 & 0 & 0 \\
\hline & Total (\%) & 3 & 11 & 28 & 26 & 20 & 10 & 2 & 1 & 0 & 0 & 0 & 0 \\
\hline \multirow[t]{2}{*}{$\begin{array}{l}\text { Burgos } \\
\text { BU-E1 }\end{array}$} & $\begin{array}{l}\text { Total no. of } \\
\text { courtyards }\end{array}$ & 15 & 26 & 35 & 62 & 54 & 17 & 3 & 0 & 0 & 1 & 0 & 0 \\
\hline & Total (\%) & 7 & 12 & 16 & 29 & 25 & 8 & 1 & 0 & 0 & 0 & 0 & 0 \\
\hline
\end{tabular}

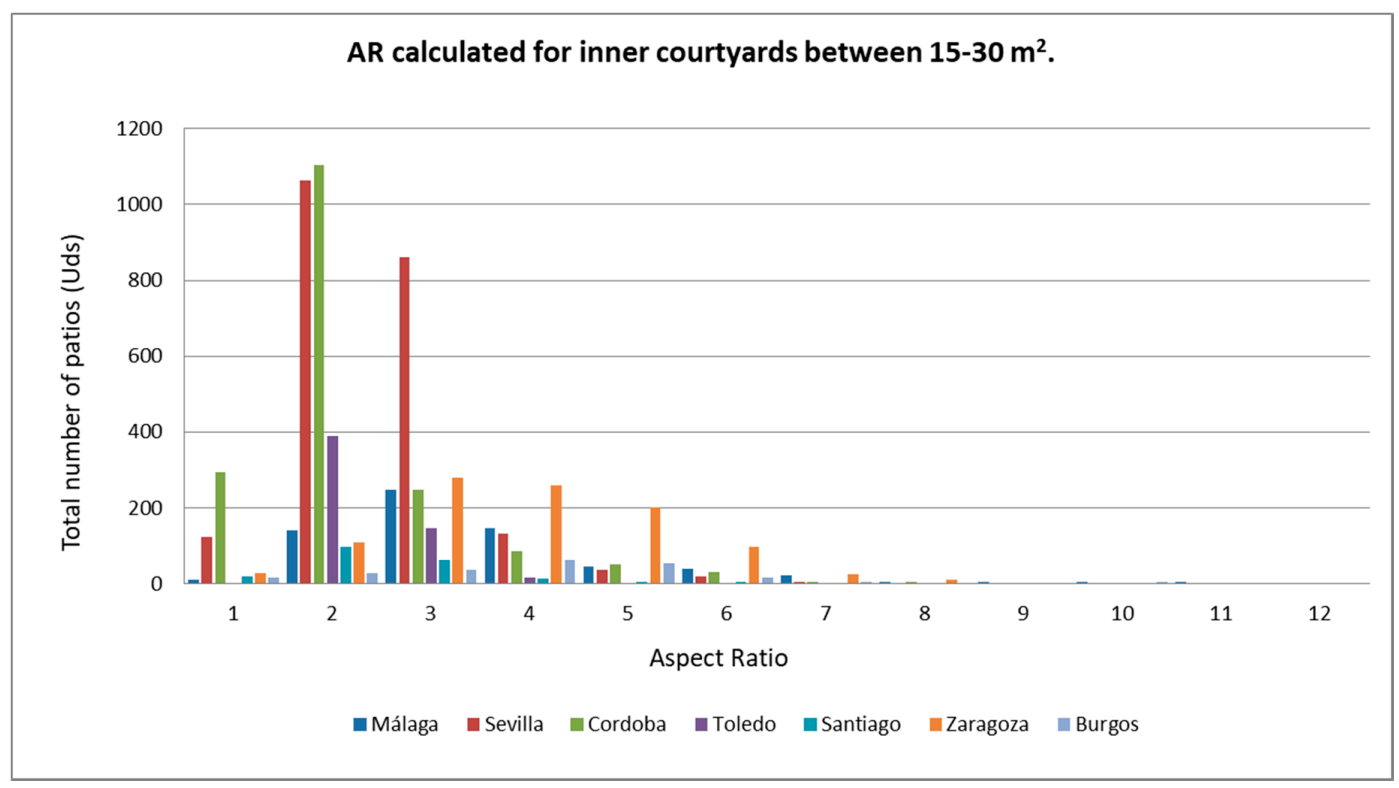

Figure 5. AR calculated for inner courtyards between 15 and $30 \mathrm{~m}^{2}$ for every city the analysed.

On the contrary, Burgos and Zaragoza have an average height above 5 levels, yet due to different reasons. Zaragoza belongs to a modern urbanism reflected in two very well defined types of courtyard: the small ventilation courtyard surrounded by high heights (AR: 5.30), and larger courtyards (15-30 $\mathrm{m}^{2}$ ) with consistently high heights (AR: 2.3 balanced for large inner courtyards). In the case of Burgos (medieval centre), both types of courtyard maintain high heights with small surfaces (AR: higher than 4.50 both cases).

\subsection{Analysis}

Table 7 shows a summary of the different data obtained for each city as shown in Figures A1-A7 (Appendix A). In relation to the total number of inner courtyards in the historic centre of each city, data confirms that those cities with highest SSI (Córdoba, Seville and Toledo) are those presenting a bigger number of courtyards (between 2805 and 13,539 units). An exceptional case is Zaragoza, due to modern urban reconfiguration of its historic centre. With a historic centre composed largely of buildings with small services inner courtyards in multi-family dwellings of $4-5$ storeys high. At the opposite end, Burgos and Santiago, with minimum SSI and a much lower number of courtyards (897-929 units). Malaga, with an intermediate SSI, has also an intermediates numbers of courtyards (2998 units). 
Table 7. Summary of the main data obtained from the analysis of the different cities.

\begin{tabular}{|c|c|c|c|c|c|c|c|c|}
\hline & & BU & $\mathrm{CO}$ & MA & SE & SA & TO & $\mathrm{ZA}^{1}$ \\
\hline UNITS & No. of COURTYARDS & 897 & 8114 & 2998 & 13,539 & 929 & 2805 & 4235 \\
\hline $\mathrm{m}^{2}$ & Standard area & 8 & 9 & 9 & 9.5 & 9 & 7 & 11.25 \\
\hline \multirow[t]{3}{*}{ Size } & $5-15 \mathrm{~m}^{2}$ & & & & & & & \\
\hline & No. of COURTYARDS & 338 & 3621 & 942 & 6108 & 312 & 1271 & 1620 \\
\hline & No. of levels & 5.24 & 3.12 & 4.37 & 3.25 & 4.00 & 3.03 & 5.22 \\
\hline $\mathbf{h} / \mathbf{w}$ & AR & 4.7 & 2.0 & 3.8 & 2.8 & 3.0 & 2.6 & 5.1 \\
\hline \multirow[t]{3}{*}{ Size } & $15-30 \mathrm{~m}^{2}$ & & & & & & & \\
\hline & No. of COURTYARDS & 213 & 1817 & 654 & 2235 & 193 & 553 & 1009 \\
\hline & No. of levels & 5.30 & 2.88 & 4.68 & 2.99 & 3.06 & 2.97 & 3.94 \\
\hline $\mathbf{h} / \mathbf{w}$ & AR & 4.6 & 1.2 & 2.9 & 2.3 & 1.9 & 1.2 & 2.3 \\
\hline
\end{tabular}

Standard area, as shown in Table 7, is the most representative courtyard area in each city, being 7-9 $\mathrm{m}^{2}$ the most typical surface except in the case of Zaragoza, that corresponds to a modern urbanism as explained above. Despite this, courtyards are classified basically in the most common areas range: 5-15 and 15-30 $\mathrm{m}^{2}$. Regarding the area of the inner courtyards, for all the studied cities, the standard courtyard is between 7 and $11.25 \mathrm{~m}^{2}$. Cities with warmer climates such as Cordoba and Seville present a similar mode of about $9.00 \mathrm{~m}^{2}$. For the rest of the cities, a significant difference can be observed: Burgos, located in the coldest climate area, presents a smaller $\left(8 \mathrm{~m}^{2}\right)$ mode, bigger than the Toledo courtyard size of around $7 \mathrm{~m}^{2}$. For the Zaragoza case, the mode is $11.25 \mathrm{~m}^{2}$, a big difference from the rest of the cities based on the modern urban development of this city.

Concerning the relation between the AR and the climatic zone, for the lower segment (courtyard area 5-15 $\mathrm{m}^{2}$ ), lowest AR corresponds to cities of greater SSI (Córdoba, Seville and Toledo). This result is consistent when one considers the size of the courtyards $\left(7-9 \mathrm{~m}^{2}\right)$ in relation to the number of storeys (3.03-3.25). This result would confirm that these inner courtyards are conceived as real areas of ventilation and shading. A higher AR is given in cases of intermediate SSI (Malaga and Zaragoza). Nevertheless, in the case of Malaga, the size of the courtyard does not remain the same $\left(9 \mathrm{~m}^{2}\right)$ with a slight increase of its height (4.37 storeys). This would be indicative of a courtyard somewhere between the traditional Mediterranean inner courtyards and the services courtyard found in Zaragoza. This same services yard is also found in Burgos and in less proportion, in Santiago, due to special planning constraints that limits the building height for heritage reasons in the historic centre of the city (UNESCO World Heritage Centre).

For the sizes between 15 and $30 \mathrm{~m}^{2}$, given that this area corresponds to multi dwelling units, the need to offer ventilation and daylight to different apartments prevails over the intention of being passive cooling elements. Despite this, lower AR values (1.2-1.9) also correspond to the cities with greater SSI. Malaga and Zaragoza have an intermediate AR consistent with their level of SSI. Burgos is the greater AR (4.6) and the lower SSI. In addition, Santiago is outside the norm for the above-mentioned urban development regulations.

\subsection{Results}

Concerning the AR for the same size of courtyard in all the different cities, significant differences can be seen for small courtyards, $5-15 \mathrm{~m}^{2}$, being the most common ones for dwellings. For all the cities located in warm climates with severe summer conditions (Cordoba, Seville and Toledo) the AR is between 2 and 2.8, while the AR increases to 4.7-5.1 for colder climates (Burgos and Zaragoza), giving rise to narrower courtyards. For bigger courtyards, $15-30 \mathrm{~m}^{2}$, for all the cities located in warm and intermediate climates (Cordoba, Malaga, Seville, Santiago and Toledo), the AR is between 1.2 and 2.9. While for colder climates, (Burgos), the AR increases to 4.6. 
In order to correctly understand these results, it is necessary to take into account some factors that are involved in this climate-courtyard relationship. In cities with colder climates such as Burgos (E1), the number of plots with courtyards is the lowest $(61 \%)$, which is consistent with the lower prevalence of inner courtyards in cold climates. However, the AR of this city is one of the highest (4.7 in 5-15 $\mathrm{m}^{2}$ courtyards) which is usually related to warmer climates in previous studies [13]. The urban structures represented in Figures A1-A7 show that the existing courtyards in these climates are usually courtyards of services. These small courtyards are usually found in blocks of apartments with very high AR. This could explain the presence of high AR courtyards in these colder cities.

\section{Thermal Courtyard Performance}

To verify the existence of a microclimate in the courtyards in dominant summer climates, which could explain the previous prevalence detected, a monitoring campaign has been developed. This campaign analysed existing buildings in the south of Spain. These case studies cover a wide range of sizes of Mediterranean courtyards.

The first case study is a central courtyard located is a 17th century traditional Andalusian palace showed in Figure 4a. It is located in the centre of Cordoba (in Figure 6a), climatic zone B4 that, according to Section 3.2 has the highest SSI in Spain. It is, therefore, a climate of very hot summers and mild winters. The courtyard selected is very characteristic of the courtyard architecture in the area, $9.57 \times 8.8 \mathrm{~m}, \mathrm{AR}=0.92$. The building is free running (naturally ventilated and without air conditioning system). The second courtyard studied is located in Malaga (Figure 6b), including dwelling and hotel uses, $28.5 \times 24.5 \mathrm{~m}, \mathrm{AR}=3.66$. The climate of this city is classified as A3, much softer and cooler in summer than the previous one.
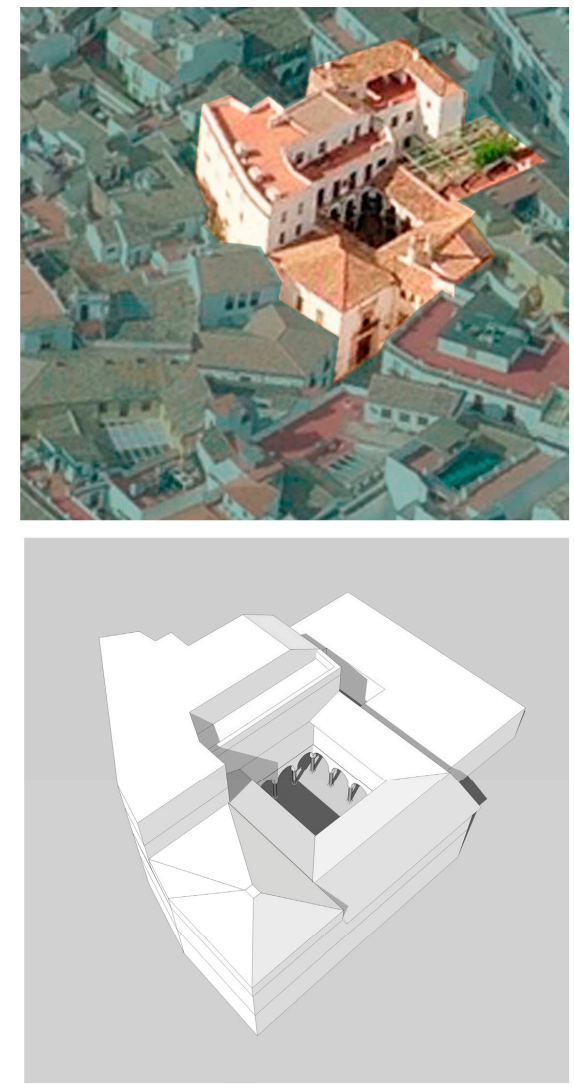

(a)
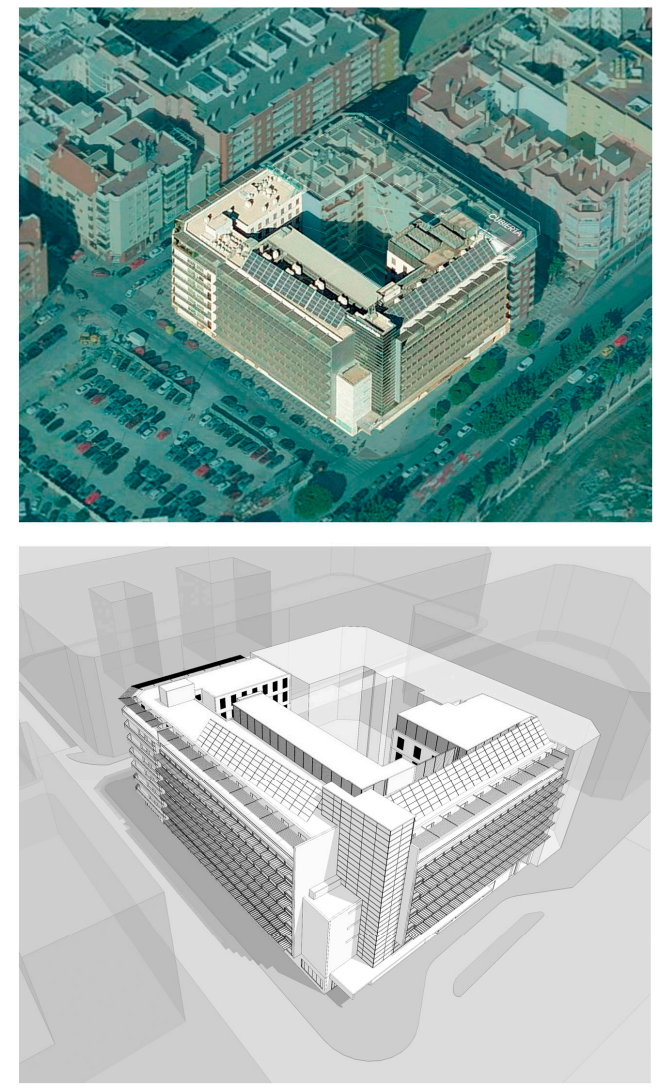

(b)

Figure 6. Building description of courtyard studied in Cordoba (a) and Malaga (b). 


\subsection{Experimental Procedure}

The surface temperature of walls, boundary layer temperature, and humidity and temperature, simultaneously in different parts of this courtyard, have been recorded. Wind speed and direction and outer temperature were also monitored in the roof of the building as well as temperature and humidity inside the building. The data loggers are specific for measuring outdoor temperatures and have been protected from the direct incidence of solar radiation. Measurement campaigns were conducted between June and October, and a week was recorded for every courtyard selected. Figure 5 shows the position of the data loggers inside the courtyard of Cordoba.

The air temperature data loggers used in the present investigation were the TESTO 174T and DOSTMANN Log 110 models. Figures 7 and 8 show the distribution of the data loggers in courtyards in Cordoba (a) and Malaga (b). The data loggers are individually calibrated and the accuracy of the certified measurement at $25^{\circ} \mathrm{C}$ is $\pm 0.5^{\circ} \mathrm{C}$. Outdoor temperature was registered using a PCE-FWS 20 weather station (Figure 5). Due to the essential importance of outdoor temperature data for the present research; they have been compared to the reliable data collected by the nearest official weather station of the Official Spanish Agency of Meteorology (AEMET) [39] located $6.94 \mathrm{~km}$ away in the outskirts, so the heat island effect for this comparison has been taken into account. It has been verified that the maximum temperatures collected do not exceed those of the official weather station.
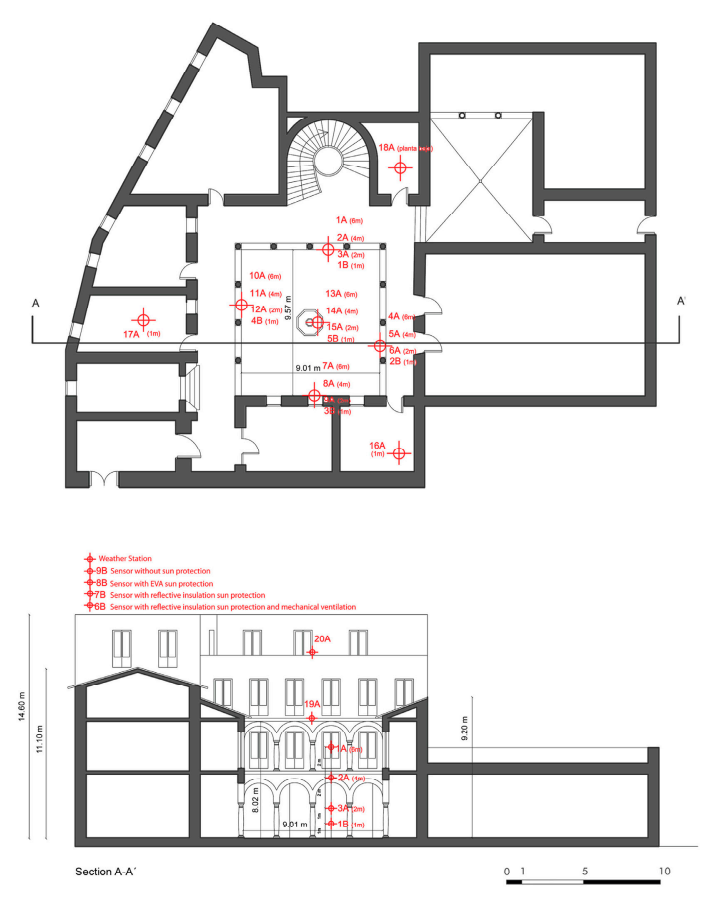

(a)

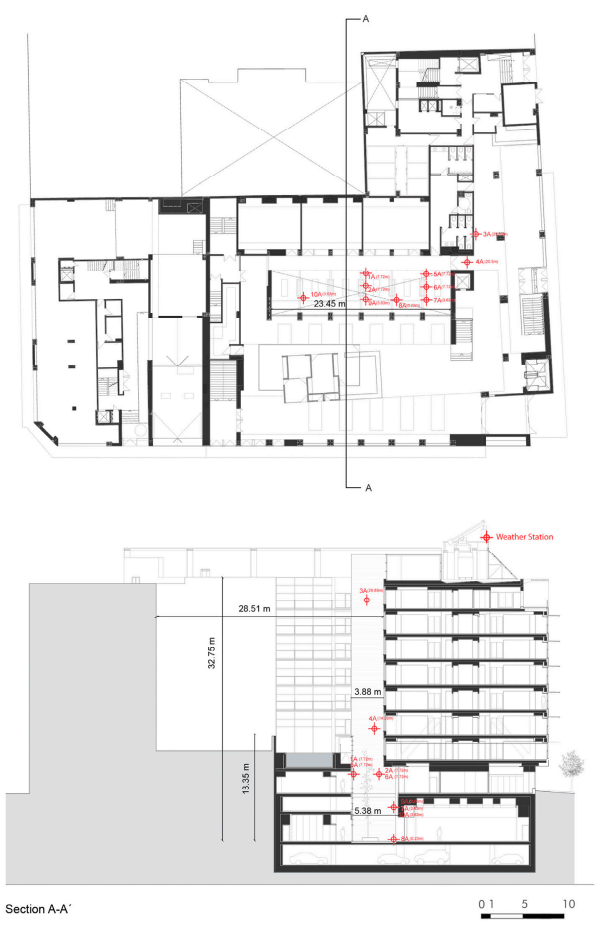

(b)

Figure 7. Floor plans and sections of the buildings in Cordoba (a) and Malaga (b) showing the data loggers' location. 

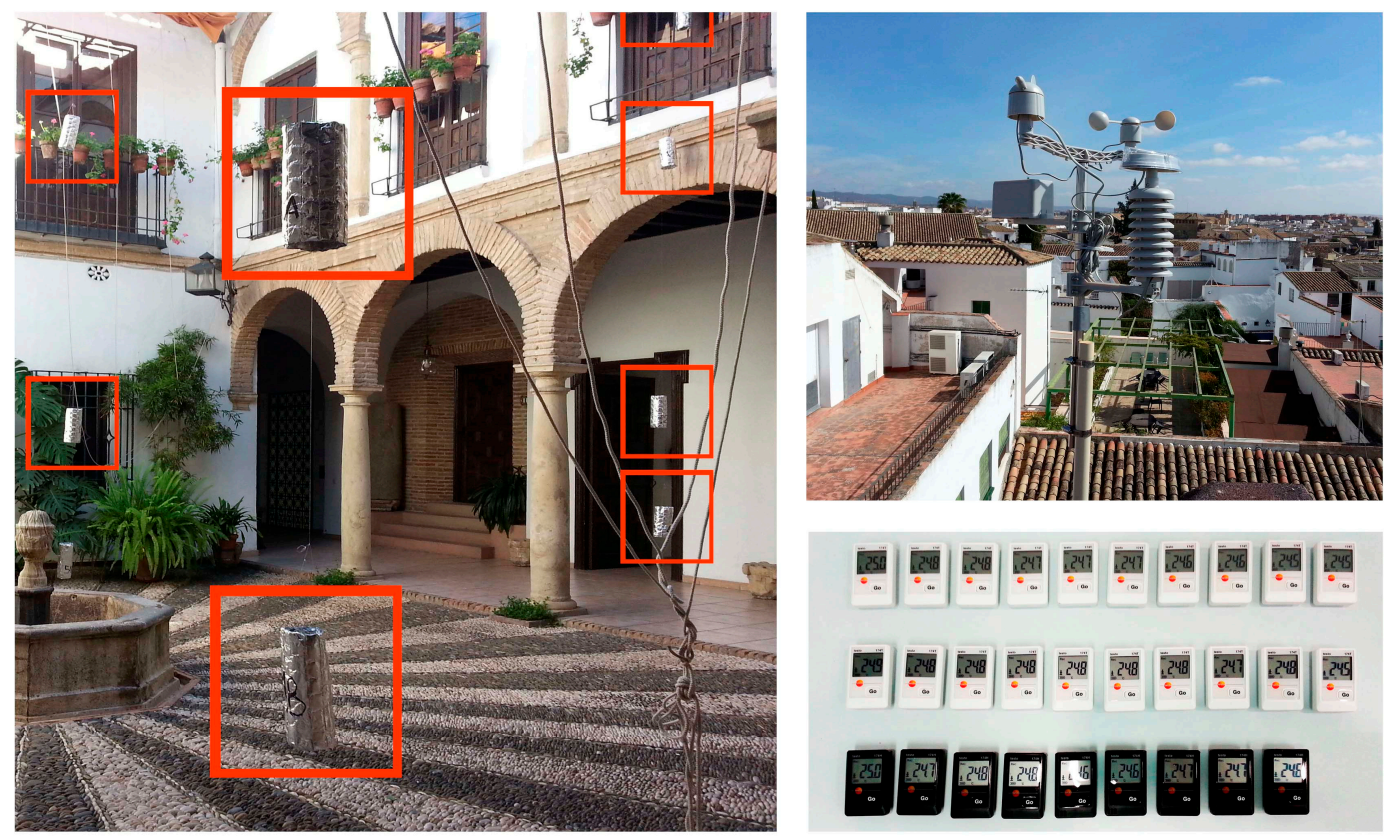

Figure 8. Monitoring campaign in Cordoba. (Left) data loggers in red boxes placed with sun protection elements to measure the air temperature; (Right) weather station on roof and data loggers.

\subsection{Results}

Figure 9 shows outdoor temperature registered on the roof of the building (red line) and outdoor temperature recorded in Córdoba by AEMET [39] (grey dashed line) [39]. The average courtyard temperature, obtained from the data logger measurements, is represented by the yellow line. It can be observed that the maximum roof temperatures recorded by this sensor are very similar to the temperatures recorded by the official AEMET. However, the minimum temperatures recorded at night by our sensor are higher than those recorded at the airport. This is as a result of the UHI Effect.

The maximum average difference between the roof and the courtyard, in the period recorded, was $6.7^{\circ} \mathrm{C}$. This is consistent with the differences recorded by other researchers [15]. These differences tend to balance at nightfall. In fact, the graph shows that sometimes the courtyard temperatures can be a few degrees higher than outside during the night and early morning due to the tempering properties of the inner courtyard.

Figure 9 shows that the courtyard temperature evolves in a lower range than the outside temperature. This implies that the courtyard is able to moderate the outer temperature, especially in the warmest hours. Most significant variation between outdoor and courtyard temperatures take place on those days when higher maximum temperatures occur. These data explain the architectural utility of the courtyard as a passive cooling system especially in dominant summer climates with extreme seasonal temperatures.

Figures 10 and 11 represent the air temperature drop monitored by the different sensors placed inside the courtyard. This drop shows a certain thermal stratification in the courtyard during the day hours. The geometries of the different courtyards have an influence in the distribution of this air temperature drop throughout the day. While in the case of Córdoba with $\mathrm{AR}=0.92$ the biggest differences are noticeable in the afternoon (18.00-20.00 h) in the case of Malaga with AR $=3.66$ the maximum difference is given at noon (11.00-12.00 h). This is explained by the influence of the shading effect due to the courtyard geometry. On the other hand the air temperature drop observed are more influenced by the summer severity of the climatic zone than by AR itself. In Cordoba where SSI $=4$ the mean maximum air temperature drop is $6.7^{\circ} \mathrm{C}$, while Malaga where SSI $=3$ despite being a deeper courtyard, mean maximum air temperature drop is $4.5^{\circ} \mathrm{C}$. 
Temperature inside and outside the courtyard

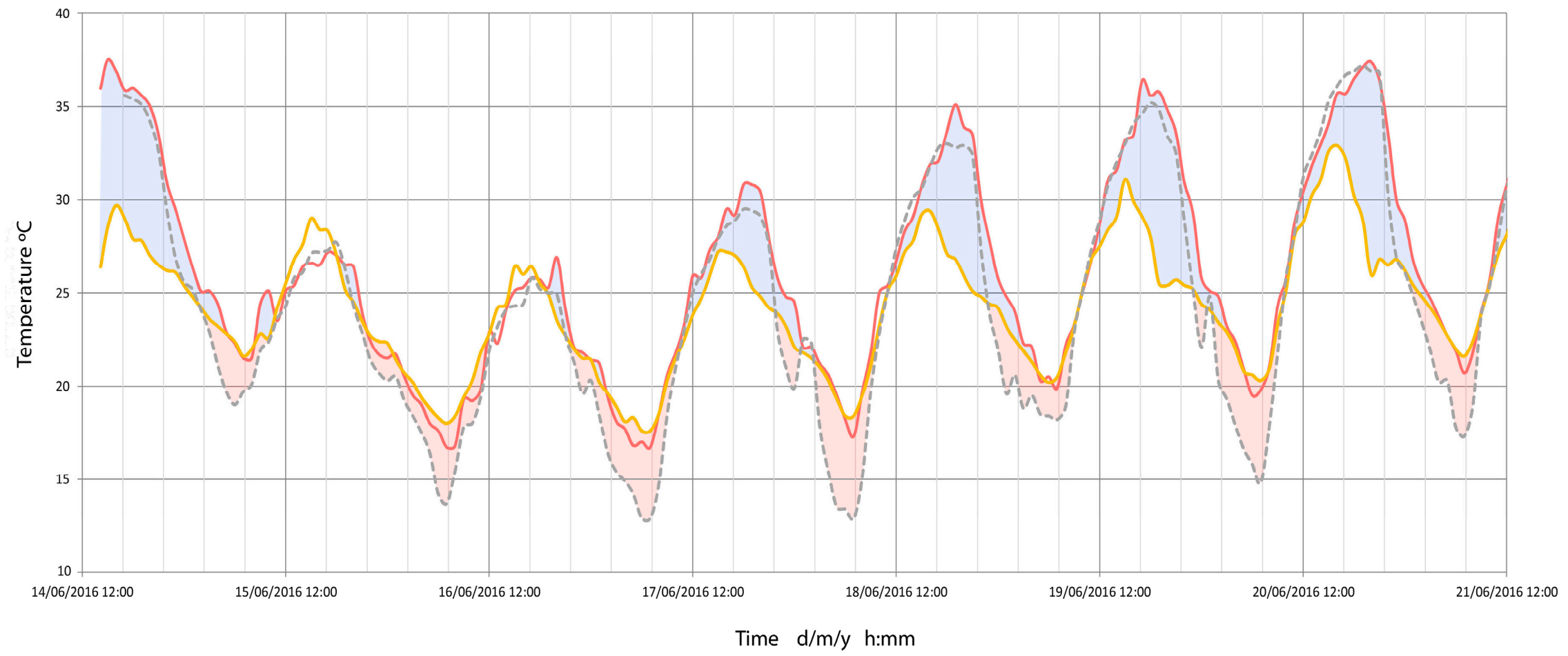

Outdoor T. Wather Station Courtyard T. $\quad=-\infty$ AEMET (Oficial Meteorological Spanish Agency in aiport)

Figure 9. Registered temperatures inside and outside (roof and AEMET [39]) in the monitored courtyard in June. Córdoba. 


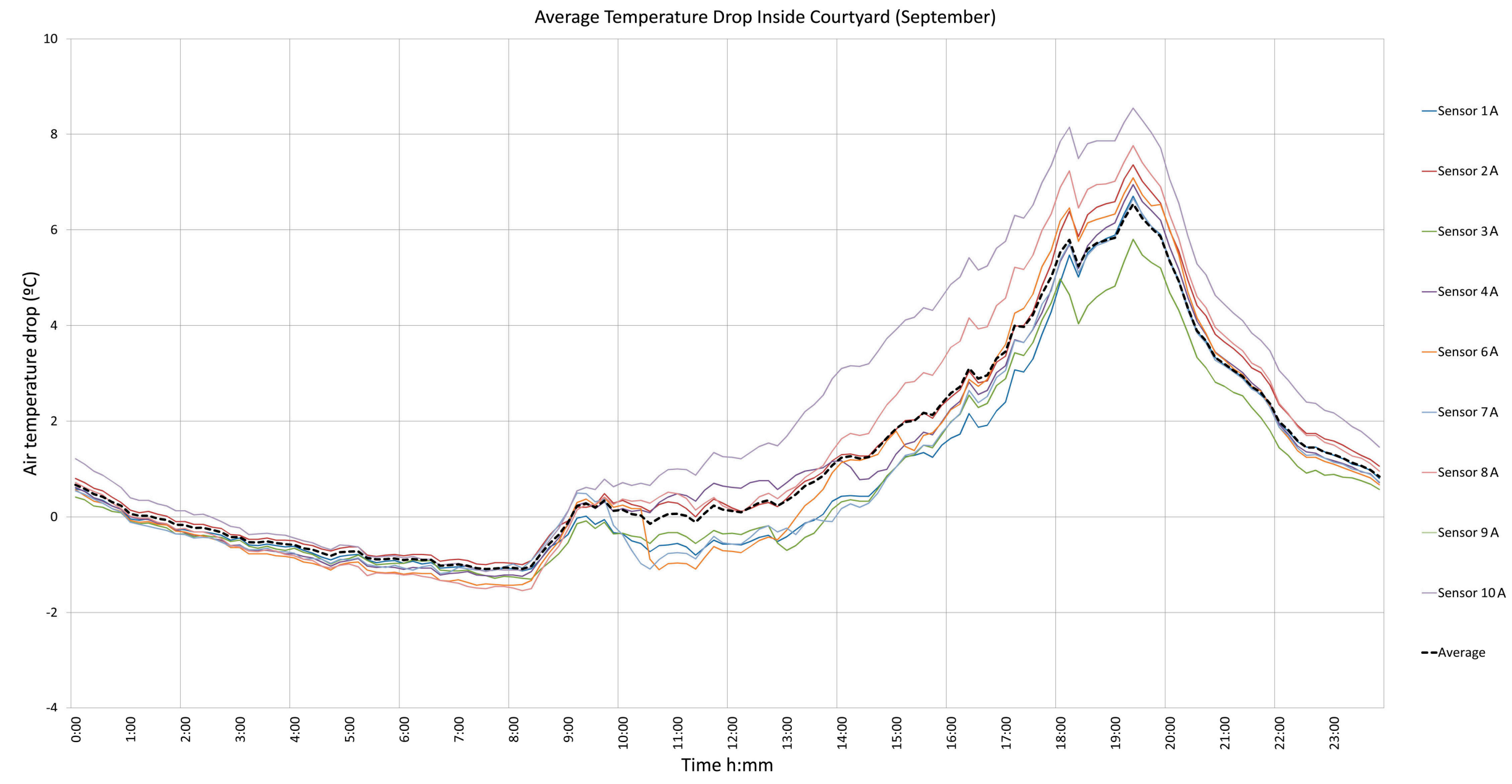

Figure 10. Registered air temperatures drop inside the monitored courtyard in Cordoba (September) AR $=0.92$. 


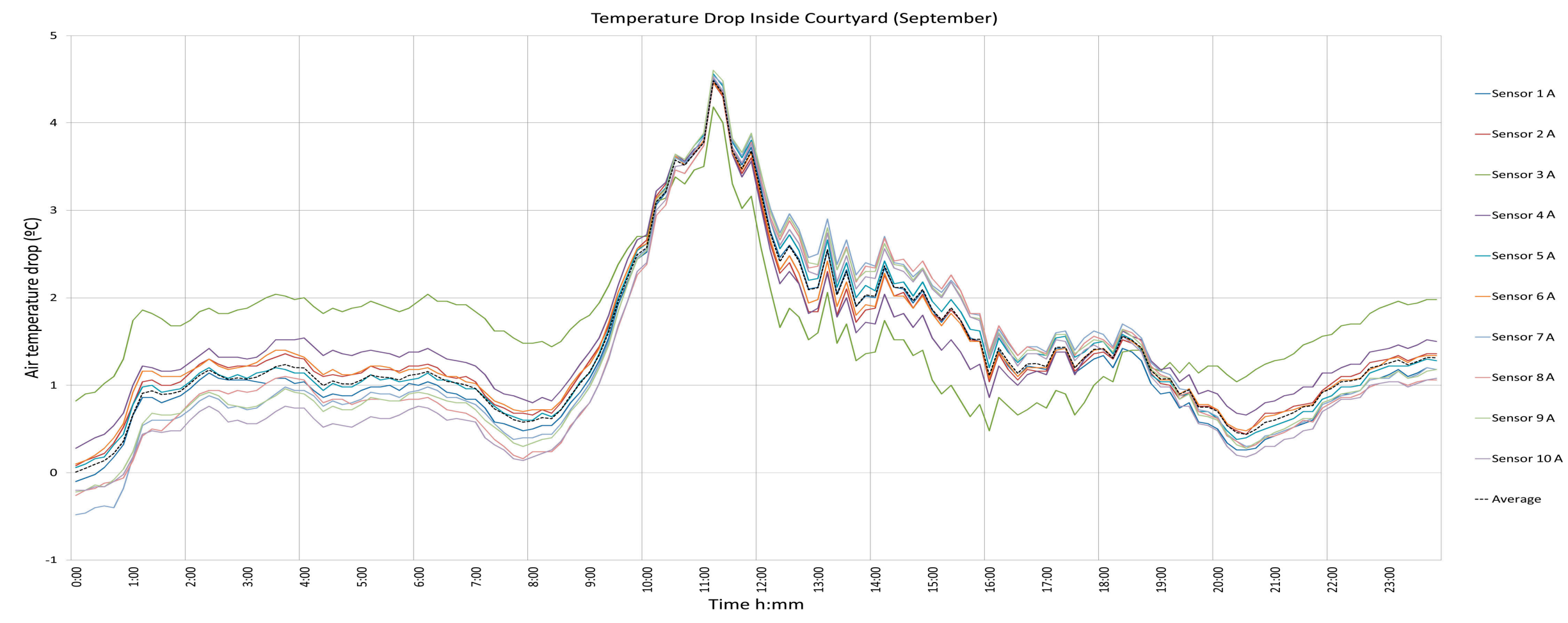

Figure 11. Registered air temperature drop inside the monitored courtyard in Malaga (September). AR = 3.66. 


\section{Conclusions}

A clear relationship between the geometrical characteristics of the courtyards and the climate zones where they are located can be established for the analysed cities. This study shows the relation between traditional architecture and the local environment. It therefore seeks the evidence that the architecture and geometry of the courtyards must modulate some characteristics of the internal microclimate, as certain shapes entail different energy consequences for the building according to the climate context. However, new regulations in Spain have standardized inner courtyards size without taking into account the adaptation of the building to the climate conditions; being this a general trend is the current architecture in Mediterranean cities.

The results of this research clearly show the greater prevalence of courtyards in cities with warmer climates. Thus, in cities with climatic zone B4, such as Cordoba, both the PI $(15 \%)$ and the percentage of plots with courtyards (82\%) are the highest. However, NPI indicates that in the studied cities with colder climates, such as Santiago (28\%), the courtyards, when existing, are much larger than in warmer climates, where they occupy a greater proportion of the plots where they are located. As it can be seen in Figure A5, these are usually backyards and not inner courtyards as the proposed ones. This city also displays the lowest percentage of plots with an inner courtyard (41\%).

Inner courtyards tempering properties have already been demonstrated by different authors in these dominant summer climates $[14-19,40]$ and checked in the monitored courtyards at a single building scale. The maximum air temperature drop in the period recorded, was $6.7^{\circ} \mathrm{C}$. Therefore, at an urban scale, the city structure that implies a variable presence, AR and sizes of courtyards in these warm-climate cities depending on the specific climate has been also showed in this paper. Despite the fact that night-time temperatures of the roof differ around $\pm 1{ }^{\circ} \mathrm{C}$ with regard to the ones inside the courtyard in the monitored cases, the thermal variation during the day is much higher and has a tempering effect that contributes globally to diminish the UHI effect.

To conclude, the link between the vernacular urban structure of the courtyards and the different climate conditions in the studied cities, remarks the importance of taking into consideration design strategies, such as building shape, in order to balance the summer severity effect in Mediterranean climates.

Acknowledgments: The authors wish to acknowledge the IUACC "Instituto Universitario de Arquitectura y Ciencias de la Construcción" for the necessary support to develop this research. This work and the costs to publish in open access have been partially funded by has been supported by the Andalusian Government Research project TEP-7985 and the National Government of Spain Research Project MTM2015-64577-C2-2-R.

Author Contributions: Galán-Marín, Rivera-Gómez and Rojas-Fernández conceived and designed the experiments; Roa-Fernández performed the experiments; Galán-Marín and Rivera-Gómez analyzed the data and wrote the paper.

Conflicts of Interest: The authors declare no conflict of interest. The founding sponsors had no role in the design of the study; in the collection, analyses, or interpretation of data; in the writing of the manuscript, and in the decision to publish the results. 


\section{Appendix A}

\section{PATIOS MALAGA}

\begin{tabular}{ll}
\hline SURFACE $\left(m^{2}\right)$ & RESULTS \\
\hline 0,0 & 0
\end{tabular}

$0-1 \quad 0$

\begin{tabular}{l|r}
\hline $1-5$ & 344 \\
\hline $5-10$ & 1153 \\
\hline
\end{tabular}

\begin{tabular}{|l|r|}
\hline $5-10$ & 1153 \\
$10-15$ & 526 \\
\hline
\end{tabular}

\begin{tabular}{l|l}
$10-15$ & -20 \\
$20-25$ & 281
\end{tabular}

$20-25$

$25-30 \quad 81$

$\begin{array}{ll}30-35 & 67\end{array}$

$35-40$

$40-45$

$45-50 \quad 45$

\begin{tabular}{l|r}
$50-55$ & 15
\end{tabular}

$55-60 \quad 21$

$60-70 \quad 30$

\begin{tabular}{l|r}
$70-80$ & 20
\end{tabular}

$80-90 \quad \mid \quad 22$

\begin{tabular}{l|l}
$90-100$ & 17 \\
$100-110$ & 20
\end{tabular}

\begin{tabular}{l|r}
$100-110$ & 20
\end{tabular}

\begin{tabular}{l|l}
$110-120$ & 12 \\
$120-140$ & 15
\end{tabular}

\begin{tabular}{l|l}
$120-140$ & 15 \\
$140-160$ & 14
\end{tabular}

\begin{tabular}{l|l}
$160-200$ & 15
\end{tabular}

\begin{tabular}{l|l}
$200-300$ & 10
\end{tabular}

\begin{tabular}{l|l}
$300-500$ & 13 \\
$500-1000$ & 10
\end{tabular}

$500-1000 \quad 10$

\begin{tabular}{lr}
$1000-3000$ & 1 \\
$>3000$ & 0 \\
\hline
\end{tabular}

2998

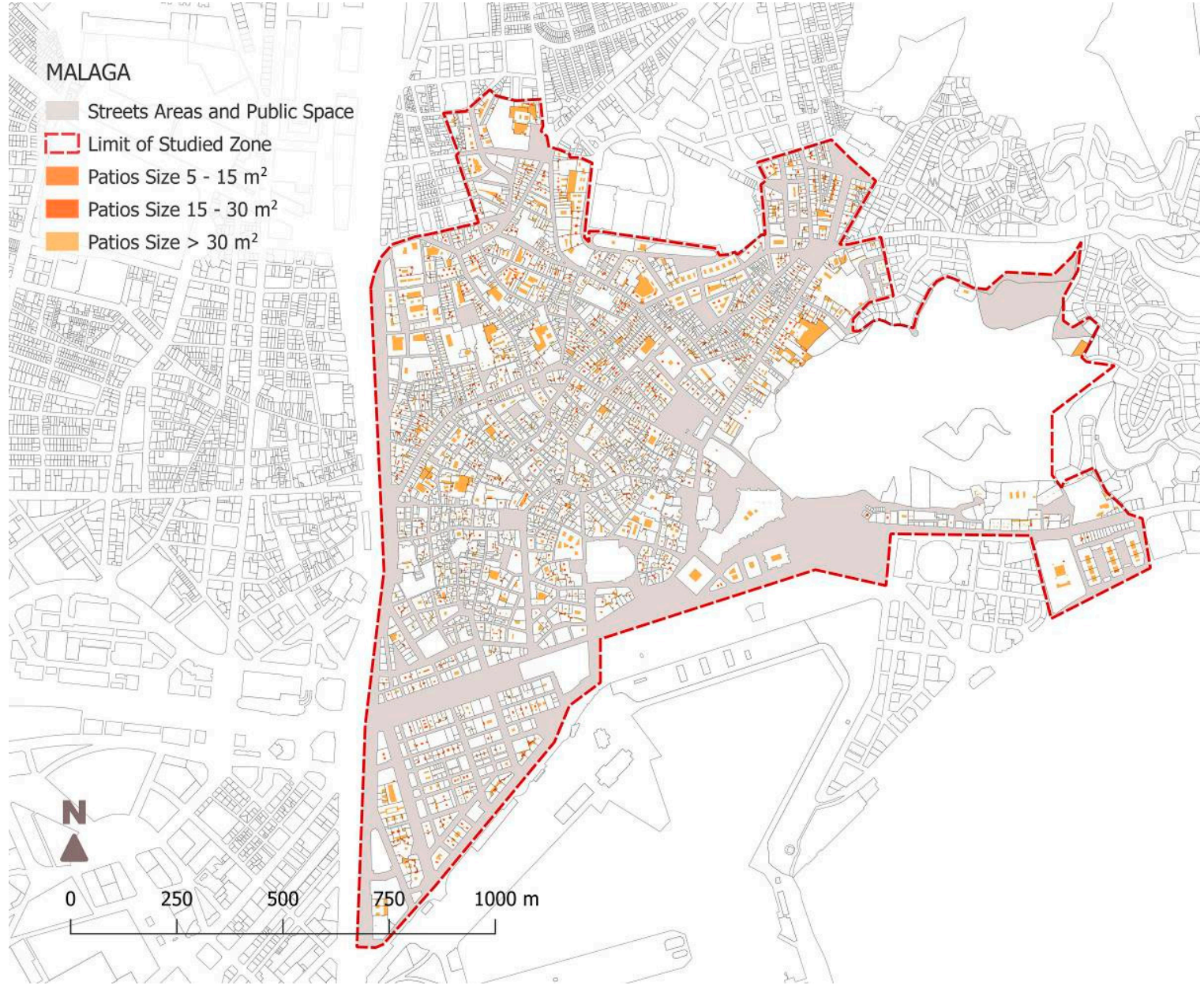

Figure A1. Plan (left) with distribution of courtyards in Malaga city centre; Courtyard sizes (right). 


\begin{tabular}{|c|c|}
\hline PATIOS & SEVILLA \\
\hline SURFACE $\left(\mathrm{m}^{2}\right)$ & RESULTS \\
\hline 0,0 & 0 \\
\hline $0-1$ & 0 \\
\hline $1-5$ & 1242 \\
\hline $5-10$ & 4642 \\
\hline $10-15$ & 2676 \\
\hline $15-20$ & 1096 \\
\hline $20-25$ & 674 \\
\hline $25-30$ & 468 \\
\hline $30-35$ & 401 \\
\hline $35-40$ & 277 \\
\hline $40-45$ & 255 \\
\hline $45-50$ & 204 \\
\hline $50-55$ & 158 \\
\hline $55-60$ & 142 \\
\hline $60-70$ & 208 \\
\hline $70-80$ & 172 \\
\hline $80-90$ & 127 \\
\hline $90-100$ & 99 \\
\hline $100-110$ & 91 \\
\hline $110-120$ & 60 \\
\hline $120-140$ & 102 \\
\hline $140-160$ & 77 \\
\hline $160-200$ & 103 \\
\hline $200-300$ & 145 \\
\hline $300-500$ & 78 \\
\hline $500-1000$ & 32 \\
\hline $1000-3000$ & 10 \\
\hline$>3000$ & 0 \\
\hline & 13539 \\
\hline
\end{tabular}

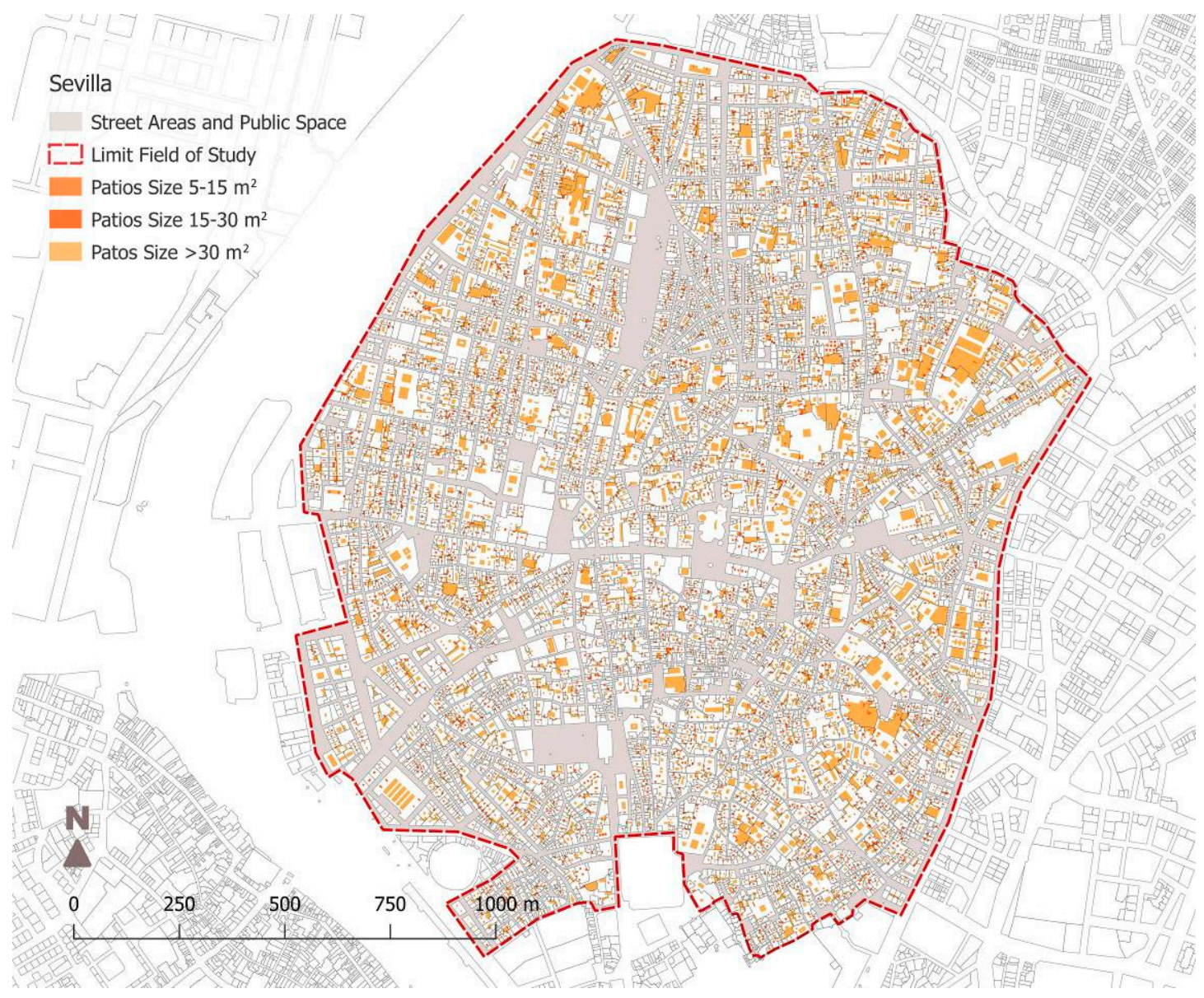

Figure A2. Plan (left) with distribution of courtyards in Seville city centre; Courtyard sizes (right). 


\begin{tabular}{|c|c|}
\hline PATIOS & CORDOBA \\
\hline SURFACE $\left(\mathrm{m}^{2}\right)$ & RESULTS \\
\hline 0,0 & 0 \\
\hline $0-1$ & 0 \\
\hline $1-5$ & 250 \\
\hline $5-10$ & 2134 \\
\hline $10-15$ & 1794 \\
\hline $15-20$ & 872 \\
\hline $20-25$ & 558 \\
\hline $25-30$ & 410 \\
\hline $30-35$ & 288 \\
\hline $35-40$ & 226 \\
\hline $40-45$ & 209 \\
\hline $45-50$ & 167 \\
\hline $50-55$ & 132 \\
\hline $55-60$ & 118 \\
\hline $60-70$ & 178 \\
\hline $70-80$ & 144 \\
\hline $80-90$ & 100 \\
\hline $90-100$ & 75 \\
\hline $100-110$ & 72 \\
\hline $110-120$ & 55 \\
\hline $120-140$ & 76 \\
\hline $140-160$ & 44 \\
\hline $160-200$ & 64 \\
\hline $200-300$ & 71 \\
\hline $300-500$ & 42 \\
\hline $500-1000$ & 26 \\
\hline $1000-3000$ & 9 \\
\hline$>3000$ & 0 \\
\hline
\end{tabular}

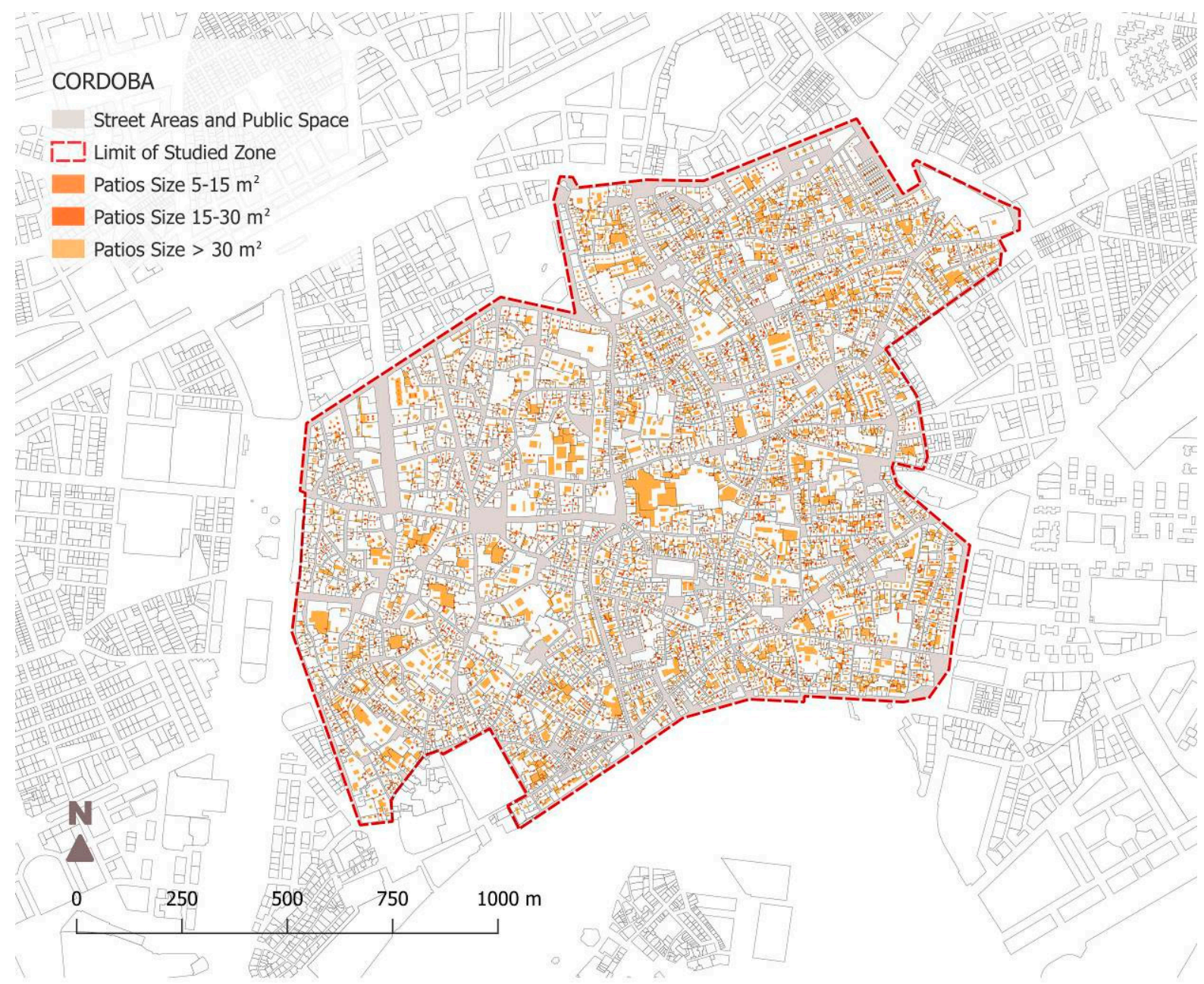

Figure A3. Plan (left) with distribution of courtyards in Córdoba city centre; Courtyard sizes (right). 


\begin{tabular}{|c|c|}
\hline PATIOS & TOLEDO \\
\hline SURFACE $\left(\mathrm{m}^{2}\right)$ & RESULTS \\
\hline 0,0 & 0 \\
\hline $0-1$ & 0 \\
\hline $1-5$ & 135 \\
\hline $5-10$ & 820 \\
\hline $10-15$ & 569 \\
\hline $15-20$ & 281 \\
\hline $20-25$ & 193 \\
\hline $25-30$ & 149 \\
\hline $30-35$ & 114 \\
\hline $35-40$ & 87 \\
\hline $40-45$ & 51 \\
\hline $45-50$ & 43 \\
\hline $50-55$ & 34 \\
\hline $55-60$ & 34 \\
\hline $60-70$ & 60 \\
\hline $70-80$ & 25 \\
\hline $80-90$ & 19 \\
\hline $90-100$ & 20 \\
\hline $100-110$ & 22 \\
\hline $110-120$ & 14 \\
\hline $120-140$ & 28 \\
\hline $140-160$ & 23 \\
\hline $160-200$ & 24 \\
\hline $200-300$ & 34 \\
\hline $300-500$ & 21 \\
\hline $500-1000$ & 3 \\
\hline $1000-3000$ & 2 \\
\hline$>3000$ & 0 \\
\hline & 2805 \\
\hline
\end{tabular}

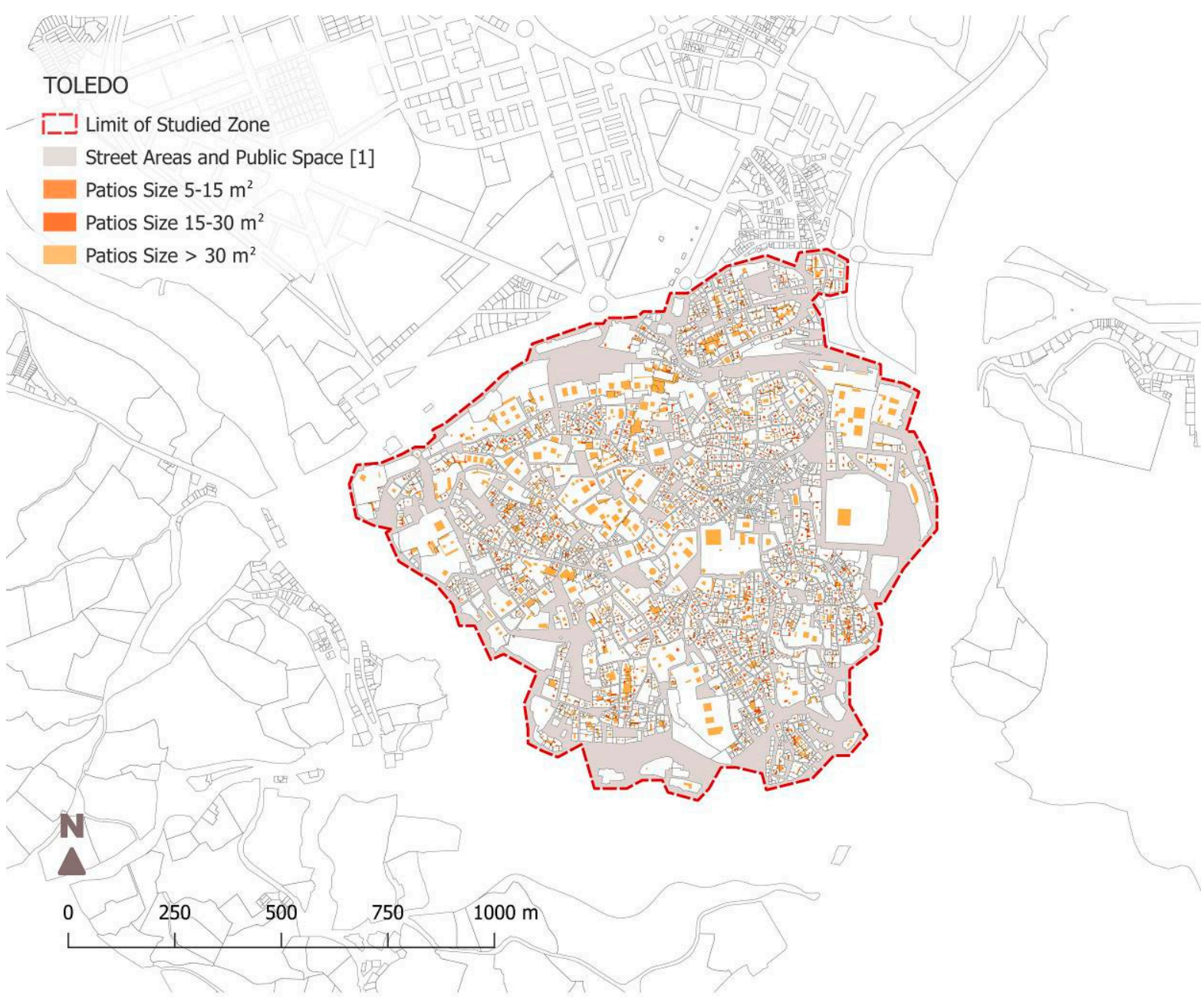

Figure A4. Plan (left) with distribution of courtyards in Toledo city centre; Courtyard sizes (right). 


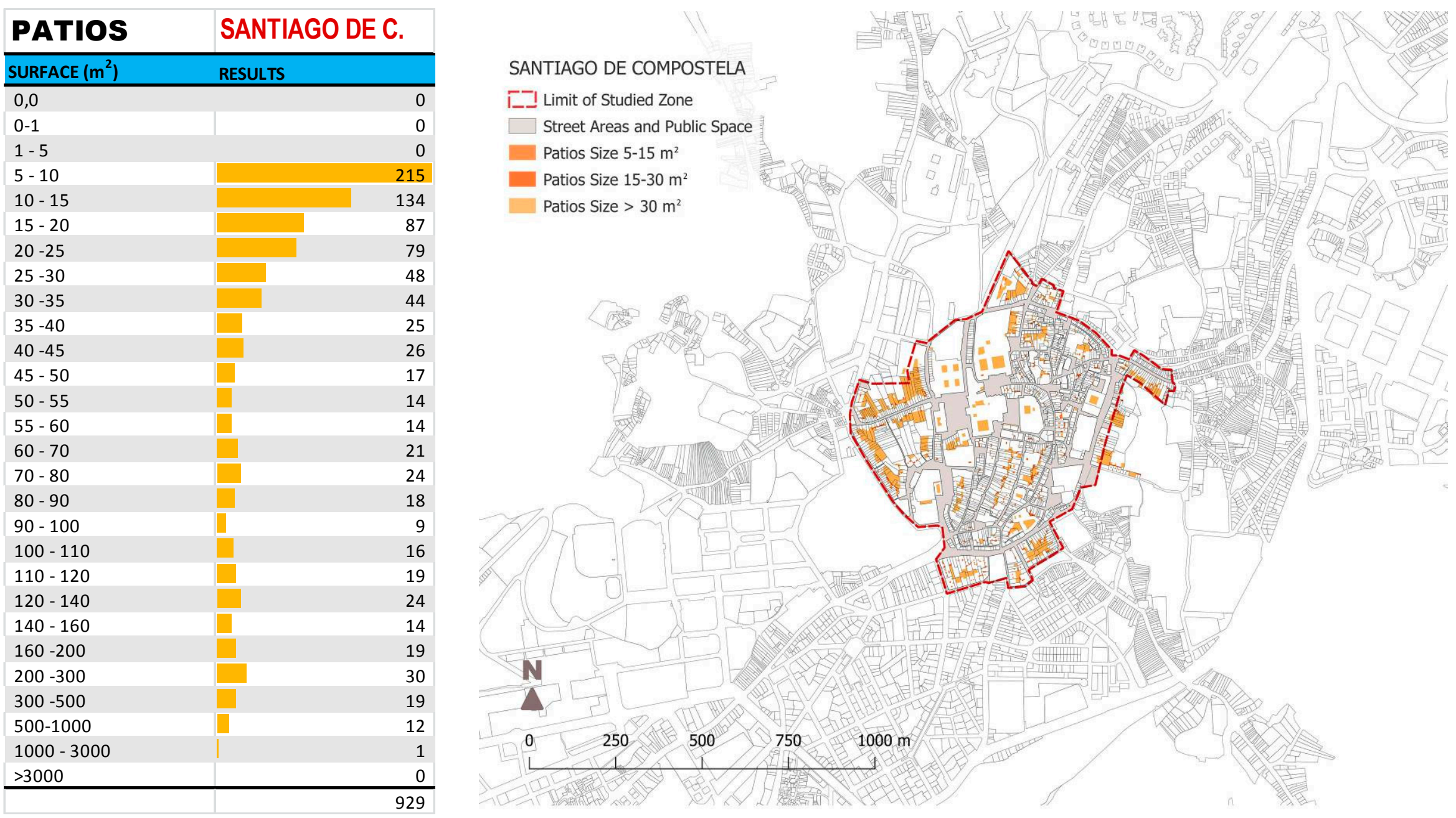

Figure A5. Plan (left) with distribution of courtyards in Santiago city centre; Courtyard sizes (right). 


\begin{tabular}{|l|r|}
\hline PATIOS & ZARAGOZA \\
\hline SURFACE $\left(\mathbf{m}^{2}\right)$ & RESULTS \\
\hline 0,0 & 0 \\
\hline $0-1$ & 0 \\
\hline $1-5$ & 145 \\
\hline $5-10$ & 936 \\
\hline $10-15$ & 749 \\
\hline $15-20$ & 473 \\
\hline $20-25$ & 308 \\
\hline $25-30$ & 233 \\
\hline $30-35$ & 170 \\
\hline $35-40$ & 130 \\
\hline $40-45$ & 121 \\
\hline $45-50$ & 116 \\
\hline $50-55$ & 85 \\
\hline $55-60$ & 63 \\
\hline $60-70$ & 91 \\
\hline $70-80$ & 82 \\
\hline $80-90$ & 74 \\
\hline $90-100$ & 49 \\
\hline $100-110$ & 38 \\
\hline $110-120$ & 42 \\
\hline $120-140$ & 68 \\
\hline $140-160$ & 42 \\
\hline $160-200$ & 61 \\
\hline $200-300$ & 70 \\
\hline $300-500$ & 40 \\
\hline $500-1000$ & 36 \\
\hline $1000-3000$ & 13 \\
\hline$>3000$ & 0235 \\
\hline & \\
\hline
\end{tabular}

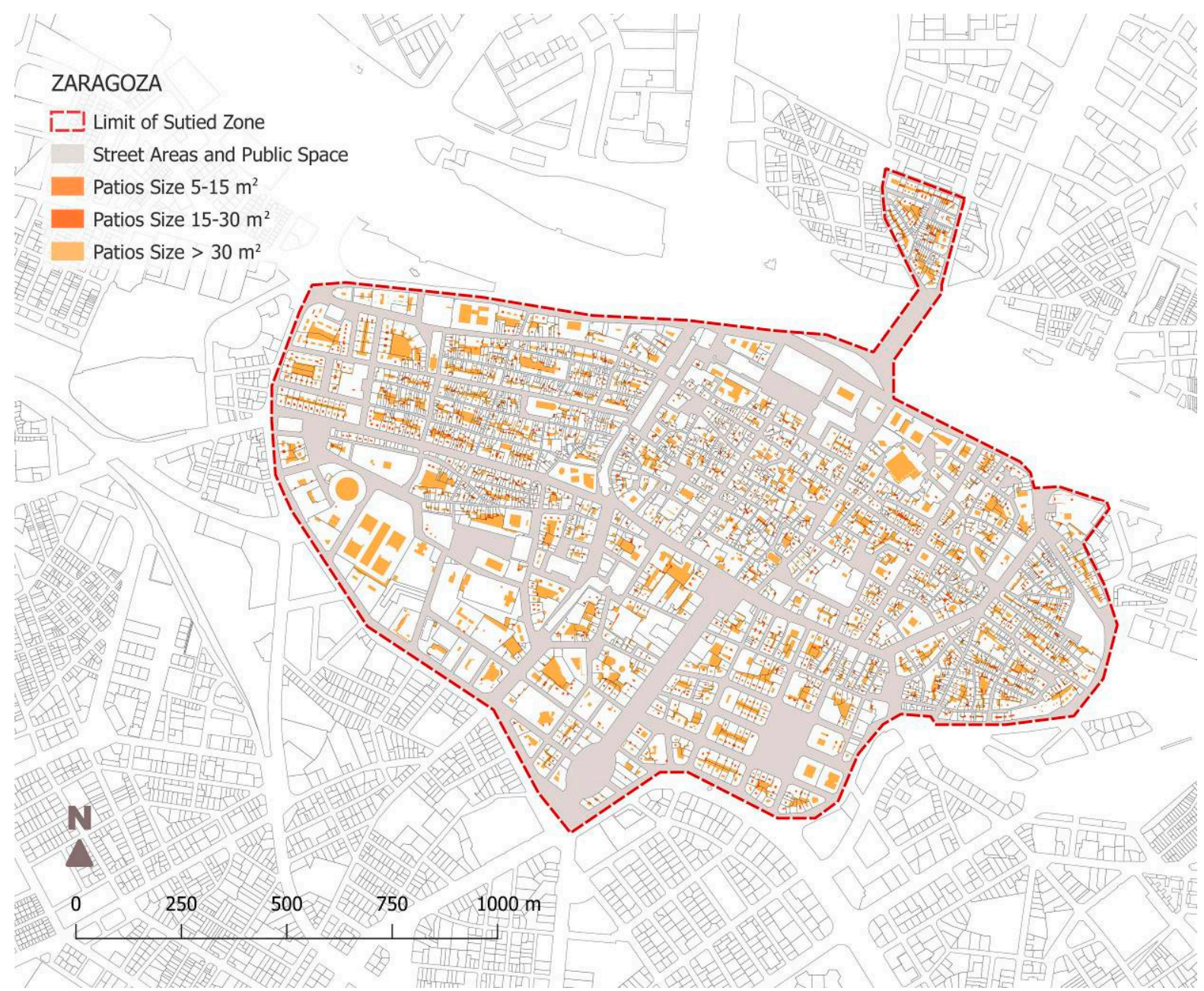

Figure A6. Plan (left) with distribution of courtyards in Zaragoza city centre; Courtyard sizes (right). 


\begin{tabular}{|l|r|}
\hline PATIOS & BURGOS \\
\hline SURFACE $\left(\mathbf{m}^{2}\right)$ & RESULTS \\
\hline 0,0 & 0 \\
\hline $0-1$ & 0 \\
\hline $1-5$ & 0 \\
\hline $5-10$ & 221 \\
\hline $10-15$ & 151 \\
\hline $15-20$ & 111 \\
\hline $20-25$ & 78 \\
\hline $25-30$ & 47 \\
\hline $30-35$ & 36 \\
\hline $35-40$ & 32 \\
\hline $40-45$ & 17 \\
\hline $45-50$ & 24 \\
\hline $50-55$ & 16 \\
\hline $55-60$ & 19 \\
\hline $60-70$ & 24 \\
\hline $70-80$ & 15 \\
\hline $80-90$ & 14 \\
\hline $90-100$ & 9 \\
\hline $100-110$ & 7 \\
\hline $110-120$ & 4 \\
\hline $120-140$ & 11 \\
\hline $140-160$ & 6 \\
\hline $160-200$ & 14 \\
\hline $200-300$ & 16 \\
\hline $300-500$ & 17 \\
\hline $500-1000$ & 7 \\
\hline $1000-3000$ & 1 \\
\hline$>3000$ & 0 \\
\hline TOTAL & 897 \\
\hline
\end{tabular}

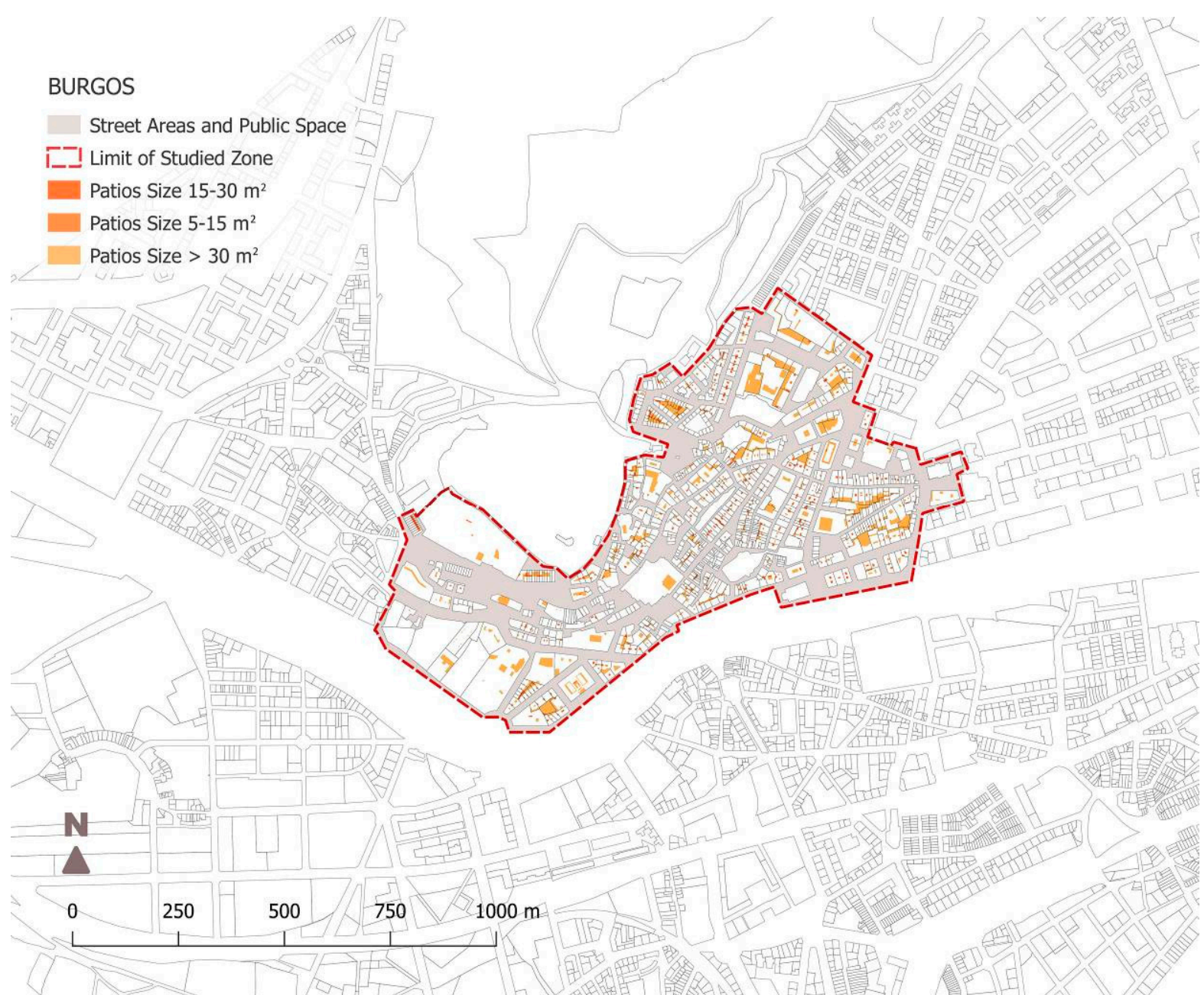

Figure A7. Plan (left) with distribution of courtyards in Burgos city centre; Courtyard sizes (right). 


\section{References}

1. Martinelli, L.; Matzarakis, A. Influence of height/width proportions on the thermal comfort of courtyard typology for Italian climate zones. Sustain. Cities Soc. 2017, 29, 97-106. [CrossRef]

2. Srebric, J.; Heidarinejad, M.; Liu, J. Building neighborhood emerging properties and their impacts on multi-scale modeling of building energy and airflows. Build. Environ. 2015, 91, 246-262. [CrossRef]

3. Jurelionis, A.; Bouris, D.G. Impact of Urban Morphology on Infiltration-Induced Building Energy Consumption. Energies 2016, 9, 177. [CrossRef]

4. Rasheed, A.; Robinson, D.; Clappier, A.; Narayanan, C.; Lakehal, D. Representing complex urban geometries in mesoscale modeling. Int. J. Climatol. 2011, 31, 289-301. [CrossRef]

5. Garcia-Nevado, E.; Pages-Ramon, A.; Coch, H. Solar Access Assessment in Dense Urban Environments: The Effect of Intersections in an Urban Canyon. Energies 2016, 9, 796. [CrossRef]

6. Levermore, G. The increasing trend of the urban heat island intensity. Urban Clim. 2017. [CrossRef]

7. Sailor, D.J. A holistic view of the effects of urban heat island mitigation. In Low Carbon Cities: Transforming Urban Systems; Lehmann, S., Ed.; Routledge: New York, NY, USA, 2014; pp. 270-281.

8. Tam, B.Y.; Gough, W.A.; Mohsin, T. The impact of urbanization and the urban heat island effect on day to day temperature. Urban Clim. 2015, 12, 1-10. [CrossRef]

9. Taleghani, M.; Kleerekoper, L.; Tenpierik, M.; van den Dobbelsteen, A. Outdoor thermal comfort within five different urban forms in The Netherlands. Build. Environ. 2015, 83, 65-78. [CrossRef]

10. Krayenhoff, E.S.; Martilli, A.; Bass, B.; Stull, R. Mesoscale simulation of urban heat mitigation strategies in Toronto, Canada. In Proceedings of the Fifth International Conference on Urban Climate, Lodz, Poland, 1-5 September 2003.

11. Yang, X.; Zhao, L.; Bruse, M.; Meng, Q. Evaluation of a microclimate model for predicting the thermal behavior of different ground surfaces. Build. Environ. 2013, 60, 93-104. [CrossRef]

12. Ghaffarianhoseini, A.; Berardi, U.; Ghaffarianhoseini, A. Thermal performance characteristics of unshaded courtyards in hot and humid climates. Build. Environ. 2015, 87, 154-168. [CrossRef]

13. Britter, R.E.; Hanna, S.R. Flow and dispersion in urban areas. Annu. Rev. Fluid Mech. 2003, 35, 469-496. [CrossRef]

14. Rojas, J.M.; Galán-Marín, C.; Fernández-Nieto, E.D. Parametric Study of Thermodynamics in the Mediterranean Courtyard as a Tool for the Design of Eco-Efficient Buildings. Energies 2012, 5, 2381-2403. [CrossRef]

15. Rodríguez Jara, E.A.; de la Flor, F.J.S.; Álvarez Domínguez, S.; Salmerón Lissén, J.M.; Rincón Casado, A. Characterizing the Air Temperature Drop in Mediterranean Courtyards from Monitoring Campaigns. Sustainability 2017, 9, 1401. [CrossRef]

16. Al-Hemiddi, N.A.; Al-Saud, K.A.M. The effect of a ventilated interior courtyard on the thermal performance of a house in a hot-arid region. Renew. Energy 2001, 24, 581-595. [CrossRef]

17. Cantón, M.A.; Ganem, C.; Barea, G.; Fernández Llano, J. Courtyards as a passive strategy in semi dry areas. Assessment of summer energy and thermal conditions in a refurbished school building. Renew. Energy 2014, 69, 437-446. [CrossRef]

18. Kubota, T.; Zakaria, M.A.; Abe, S.; Hooi, D.; Toe, C. Thermal functions of internal courtyards in traditional Chinese shophouses in the hot-humid climate of Malaysia. Build. Environ. 2017, 112, 115-131. [CrossRef]

19. Taleghani, M.; Tenpierik, A.; van den Dobbelsteen, A.; Sailor, D.J. Heat in courtyards: A validated and calibrated parametric study of heat mitigation strategies for urban courtyards in the Netherlands. Sol. Energy 2014, 103, 108-124. [CrossRef]

20. Olgyay, M.V. Design with Climate; Princeton University Press: Princeton, NJ, USA, 1963.

21. Oke, T.R. Boundary Layer Climates; Routledge: New York, NY, USA, 1987.

22. Givoni, B. Climate Considerations in Building and Urban Design; Wiley: Hoboken, NJ, USA, 1998.

23. Yezioro, A.; Capeluto, I.G.; Shaviv, E. Design guidelines for appropriate insolation of urban squares. Renew. Energy 2006, 31, 1011-1023. [CrossRef]

24. Steemers, K.; Baker, N.; Crowther, D.; Dubiel, J.; Nikolopoulou, M.H.; Ratti, C. City texture and microclimate. Urban Des. Stud. 1997, 3, 25-50.

25. Chrisman, N.R. What Does 'GIS' Mean? Trans. GIS 1999, 3, 175-186. [CrossRef] 
26. De Luis, F.; Pérez-García, M. Parametric study of solar gains in saw-tooth roofs facing the equator. Renew. Energy 2004, 29, 1223-1241. [CrossRef]

27. Muhaisen, A.S.; Gadi, M.B. Mathematical model for calculating the shaded and sunlit areas in a circular courtyard geometry. Build. Environ. 2005, 40, 1619-1625. [CrossRef]

28. Muhaisen, A.S.; Gadi, M.B. Effect of courtyard proportions on solar heat gain and energy requirement in the temperate climate of Rome. Build. Environ. 2006, 41, 245-253. [CrossRef]

29. Muhaisen, A.S.; Gadi, M.B. Shading performance of polygonal courtyard forms. Build. Environ. 2006, 41, 1050-1059. [CrossRef]

30. Muhaisen, A.S. Shading simulation of the courtyard form in different climatic regions. Build. Environ. 2006, 41, 1731-1741. [CrossRef]

31. Tabesh, T.; Sertyesilisik, B. An Investigation into Energy Performance with the Integrated Usage of a Courtyard and Atrium. Buildings 2016, 6, 21. [CrossRef]

32. QGIS 2.18. Available online: http://www.qgis.org/en/site/ (accessed on 14 May 2017).

33. Dirección General del Catastro. Ministerio de Hacienda y Función Pública. Gobierno de España. Available online: http:/ / www.catastro.minhap.gob.es/webinspire/index.html (accessed on 14 May 2017).

34. Directive 2007/2/EC of The European Parliament and of The Council of 14 March 2007 Establishing an Infrastructure for Spatial Information in the European Community (INSPIRE). Available online: http:/ /inspire. ec.europa.eu/legislation-details/directive-20072ec-european-parliament-and-council (accessed on 14 June 2017).

35. Hall, D.J.; Walker, S.; Spanton, A.M. Dispersion from courtyards and other enclosed spaces. Atmos. Environ. 1999, 33, 1187-1203. [CrossRef]

36. Marciotto, E.R.; Oliveira, A.P.; Hanna, S.R. Modelling study of the aspect ratio influence on urban canopy energy fluxes with a modified wall-canyon energy budget scheme. Build. Environ. 2010, 45, 2497-2505. [CrossRef]

37. Yang, X.; Li, Y. The impact of building density and building height heterogeneity on average urban albedo and street surface temperature. Build. Environ. 2015, 90, 146-156. [CrossRef]

38. CTE. Código Técnico de la Edificación. Documento Básico de Ahorro de Energía. Available online: http:/ / www.idae.es/tecnologias/eficiencia-energetica/edificacion/codigo-tecnico-de-la-edificacion (accessed on 2 June 2017).

39. Agencia Estatal de Meteorología (AEMET). Gobierno de España, 2016; Agencia Estatal de Meteorología (AEMET): Madrid, Spain, 2016; Available online: http:/ /www.aemet.es/es/portada (accessed on 23 June 2016).

40. Rojas-Fernández, J.M.; Galán-Marín, C.; Fernández-Nieto, E. Microclimatic conditions of internal courtyards in warm climates and their influence in eco-efficient construction. In Proceedings of the Passive and Low Energy Architecture, Design to Drive (PLEA), Edinburgh, UK, 3-5 July 2017; pp. 649-657. 